\title{
Potensi dampak Airbnb terhadap usaha penyediaan akomodasi di Provinsi DKI Jakarta
}

\author{
Addin Maulana $^{{ }^{*}}$, M. Iqbal Rosyidi ${ }^{1}$, Chamma Fitri Putri Pradjwalita Koesfardani ${ }^{1}$, Septia Awal \\ Hidayah $^{1}$, I Dewa Gede Richard Alan Amory ${ }^{1}$ \\ ${ }^{1}$ Kementerian Pariwisata \\ *addin.maulana@yahoo.co.id
}

\begin{abstract}
ABSTRAK
Berkembangnya platform Airbnb di Indonesia pada umumnya dan di DKI Jakarta khususnya menuntut pemerintah untuk bertindak cepat dalam menjaga persaingan usaha yang sehat. Menggunakan pendekatan deskriptif dengan mengeksplorasi fenomena sosial melalui studi kepustakaan, Focus Group Discussion (FGD), serta peramalan, kajian ini berhasil mengidentifikasi potensi dampak Airbnb terhadap usaha penyediaan akomodasi. Hingga bulan Juli 2018 lalu, telah terdapat 5.494 listing host, di mana 254 host atau 7\% nya memiliki banyak listing. Pendapatan tertinggi Airbnb tercatat mencapai Rp 14,4 miliar per bulan, dengan peningkatan rata-rata sebesar 6,25\%. Data pengguna jasa Airbnb juga menunjukkan komposisi tamu asing dan domestik yang semakin tipis perbedaannya. Dengan menggunakan peramalan, diperkirakan jenis listing Entire Home akan memiliki tingkat penghunian yang sama dengan hotel bintang pada Juni 2023 dan hotel non bintang pada bulan November 2023. Potensi penerimaan pajak dari Airbnb dapat mencapai Rp 1,5 miliar per bulan. Masih minimnya peraturan mengenai digital platform menuntut pemerintah untuk segera membuat kebijakan guna menjaga kondisi usaha yang sehat seperti membuat peraturan pengelolaan usaha penyediaan akomodasi berbasis digital, kebijakan zonasi kepemilikan, pengawasan sosial dan lingkungan, serta pengawasan terhadap platform Airbnb dan sejenisnya.
\end{abstract}

Kata kunci: Usaha Penyediaan Akomodasi, Potensi Dampak, Airbnb

Klasifikasi JEL: Z30, Z32, Z31

\section{ABSTRACT}

The expansion of the Airbnb platform in Indonesia in general and in DKI Jakarta in particular, requires an immediate response from the government in maintaining fair business competition. Using a descriptive approach by exploring social phenomena through library studies, Focus Group Discussions and forecasting, this study successfully identified Airbnb's potential impact on the accommodation business. Until July 2018, there were 5,494 host listings, of which 254 hosts or 7\% had multiple listing. The highest revenue recorded at IDR 14.4 billion per month, with an average increase of $6.25 \%$. Data on Airbnb service users also shows the composition of foreign and domestic guests, which is getting narrow. Forecasting shows that the Entire Home listing type will have the same occupancy rate as star hotels in June 2023 and non-star hotels in November 2023. The potential tax revenue from Airbnb can reach IDR 1.5 billion per month. The inadequate of regulations regarding digital platforms requires the government to immediately make policies to maintain healthy business conditions such as making regulations on the management of digital-based accommodation business, ownership zoning policies, social and environmental surveillance, as well as control of the Airbnb platform and other similar platform.

Keywords: Business Accommodation, Potential Impact, Airbnb

JEL Classification: Z30, Z32, Z31

\section{PENDAHULUAN}

Sejak tahun 2013, sharing platforms GOJEK (platform transportasi online) telah berkembang di Indonesia bersamaan dengan pengenalan pada sharing platform UBER dan Airbnb (Liem, 2016). Platform ini tidak memerlukan waktu yang lama untuk mengambil hati konsumen, dengan kemudahan yang diberikan serta tawaran peningkatan efisiensi kepada konsumen yang menjadi daya tarik tersendiri bagi platform ini. Namun, seiring dengan perkembangannya yang pesat, muncul konflik antara platform ini dengan pelaku usaha yang masih menjalankan model bisnisnya secara tradisional yang sebelumnya sudah ada (traditional platform). Beberapa penolakan dikarenakan singgungan yang terjadi antara sharing platform dan traditional platform. Hal ini terjadi karena jenis usaha yang dijalankan 
oleh sharing platform umumnya merupakan usaha tradisional yang mengalami penambahan nilai dengan menggunakan teknologi informasi yang berkembang. Sharing platform transportasi saat ini sebagai contohnya, telah mengalami banyak penolakan beroperasi, baik dari pengusaha industri transportasi tradisional (angkot, taksi, dan lainnya) maupun dari penduduk sekitar destinasi wisata yang menggantungkan hidupnya dari hasil usaha jasa bidang transportasi lokal di daerahnya (ojek, penyewaan kendaraan, dan lainnya).

Beberapa daerah di Indonesia seperti Jawa Barat, Yogyakarta, Banyumas, Batam, Malang, dan Pekanbaru sudah mengeluarkan pernyataan menolak beroperasinya sharing platform (Sahroji, 2017). Hal yang sama juga terjadi di Kabupaten Garut (Aini, 2017), Kota Kediri (Saputra, 2017), Kota Salatiga (Setiawan, 2017), Kota Bukittinggi (Erlangga, 2017), beberapa kawasan wisata di Bali (Soni, 2016), serta Banyuwangi (Anugrah, 2017). Penolakan yang sama juga terjadi pada sharing platform usaha penyediaan akomodasi Airbnb di Indonesia. Perhimpunan Hotel dan Restoran Indonesia (PHRI) pada Desember 2017 lalu menyatakan penolakan terhadap platform ini karena telah melanggar peraturan yang telah ditetapkan, dan meminta Kementerian Komunikasi dan Informatika (Kominfo) untuk melarang platform tersebut beroperasi di Indonesia (Fitriyani, 2017).

Airbnb bukan satu-satunya sharing accommodation platform di dunia. Sejumlah platform yang memiliki model bisnis seperti Airbnb, di antaranya VRBO, Tripping.com, Flipkey, dan OneFineStay. Meskipun demikian, Airbnb sudah telah lama dikenal dan telah banyak digunakan olah traveler yang berkunjung ke Indonesia. Tercatat hingga tahun 2017, sebanyak 43.700 usaha penyediaan akomodasi telah terdaftar dan sudah melayani lebih dari 800.000 tamu, dengan pemasukan terhadap mereka yang menyewakannya lebih dari Rp 1 triliun (Prakoso, 2017). Dengan tingkat pertumbuhan Airbnb di Indonesia mencapai $72 \%$ dari tahun ke tahun, tuan rumah memperoleh sekitar Rp1,23 triliun (US 91 juta), di mana 97\% pendapatannya kembali ke komunitas lokal tempat tuan rumah tersebut berada (Prakoso, 2017). Industri perhotelan saat ini sudah merasa terancam dengan keberadaan platform ini (Cahyani, 2017). Dugaan pelanggaran terhadap pajak serta peraturan terkait pendirian usaha akomodasi menjadi dasar kekhawatiran dari para pengusaha bidang industri akomodasi (Nurlaila, 2017). Gelombang penolakan sharing platform usaha penyediaan akomodasi terjadi sejak akhir tahun 2017 lalu. Hal ini tentu perlu disikapi bersama agar konflik tidak berkelanjutan.

Jika mengacu kepada Undang-Undang No. 10/2009 tentang Kepariwisataan pasal 19, maka peraturan tersebut menyatakan dengan jelas bahwa setiap orang berhak untuk terlibat dalam pariwisata, baik sebagai pemenuh kebutuhan, melakukan usaha, menjadi pekerja, dan bentuk keterlibatan yang lain dalam pembangunan kepariwisataan (Kementerian Hukum dan HAM, 2009). Artinya, bahwa tidak ada suatu larangan bagi masyarakat yang berada di dalam suatu destinasi untuk membuka usaha guna memenuhi kebutuhan wisatawan yang berkunjung ke destinasi tersebut. Masalah umumnya timbul jika terjadi konflik antar pemangku kepentingan yang ada di wilayah atau destinasi tersebut. Apabila jenis usaha yang muncul pada umumnya tidak bersinggungan dengan usaha yang sudah umumnya dijalankan, maka kecil kemungkinan terjadinya konflik. Untuk itu, diperlukan suatu kajian terkait permasalahan tersebut, dengan melihat beberapa aspek penting, antara lain: peraturan dan perundang-undangan yang berlaku, serta identifikasi potensi dampak kemunculan fenomena tersebut terhadap kondisi industri pariwisata khususnya penyedia jasa akomodasi. Oleh karena itu, dapat dirumuskan masalah yang diangkat adalah perkembangan usaha penyediaan akomodasi di Provinsi DKI Jakarta, perkembangan platform peer-to-peer economy Airbnb serta melihat dampaknya terhadap usaha penyediaan akomodasi dan dampak penerimaan pajak dari kemunculan peer-to-peer platform Airbnb di Provinsi DKI Jakarta.

Penelitian ini bertujuan untuk mengidentifikasi potensi dampak platform peer-to-peer economy Airbnb terhadap usaha penyediaan akomodasi di Provinsi DKI Jakarta. Hasil penelitian diharapkan dapat menjadi masukkan bagi pemangku kepentingan, guna merumuskan kebijakan terkait kemunculan platform digital pada jenis usaha akomodasi yang masuk dalam pengelolaan Pemerintah. 


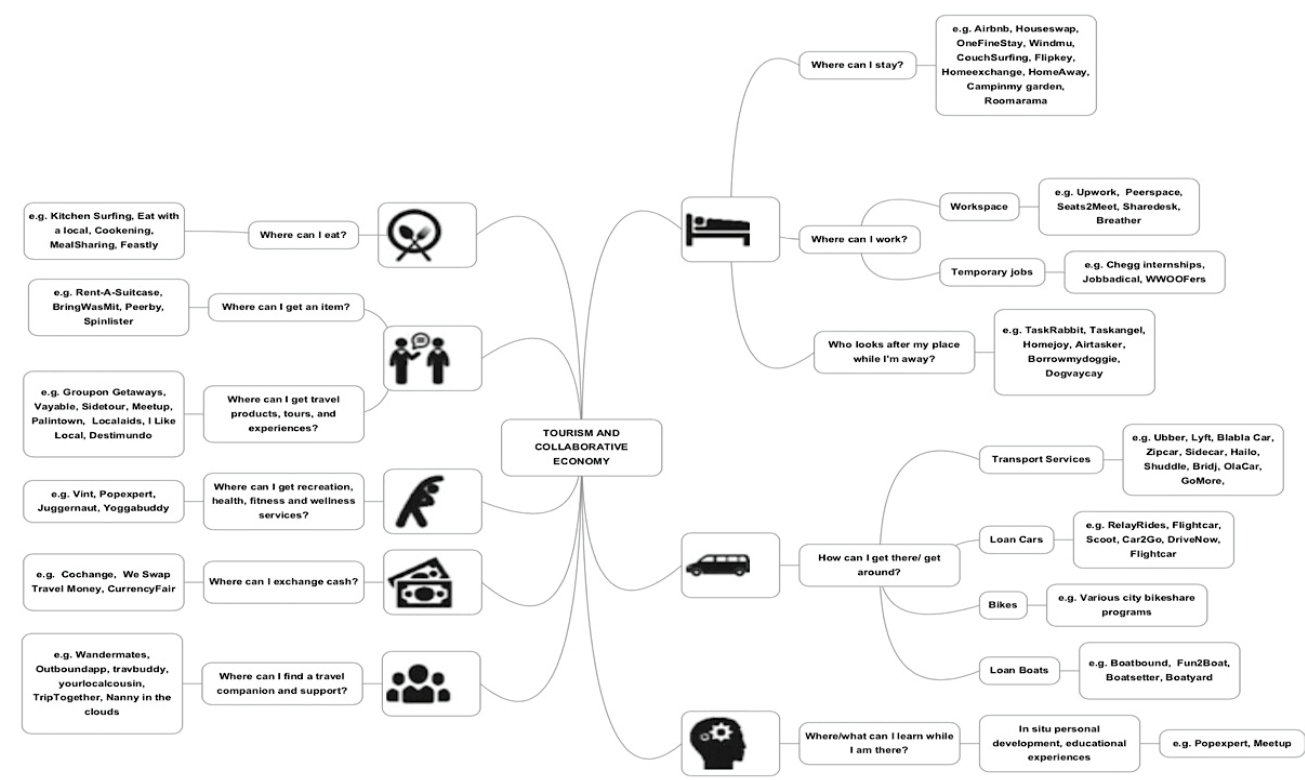

Sumber: Dredge dan Gyimothy (2017)

Gambar 1. The Collaborative Economy and Tourism

\section{TINJAUAN PUSTAKA}

Sharing economy merupakan kata lain dari collaborative economy, gift economy, access economy, on-demand economy (Dredge \& Gyimothy, 2017). Menurut Botsman dan Rogers (2010) sharing economy dapat juga diartikan sebagai sebagai model ekonomi yang digerakkan oleh teknologi jaringan yang memungkinkan berbagai hal dan keterampilan untuk dibagikan atau dipertukarkan dengan cara dan dalam skala yang sebelumnya mustahil untuk dilakukan (Juul, 2015). Oleh karena itu, dapat dikatakan bahwa sharing economy memberikan nilai tambah (value added) kepada ekonomi tradisional dalam sisi pengelolaannya. Adapun hal yang dikelola oleh ekonomi jenis ini sebenarnya merupakan usaha tradisional yang sebelumnya sudah ada, namun dengan perkembangan teknologi, siapapun memiliki peluang untuk membuka usaha yang sama dari apa yang mereka miliki dengan cara berbagi.

Pariwisata merupakan salah satu sektor yang terpengaruh dengan fenomena ini. Pemenuhan kebutuhan wisatawan merupakan salah satu aktivitas ekonomi dalam pariwisata. Dengan sharing economy, pemenuhan kebutuhan wisatawan tidak saja menjadi peluang bagi para pelaku usaha penyediaan akomodasi, namun lebih luas kepada penduduk/masyarakat yang tinggal di destinasi, dimana mereka dapat dengan mudah terhubung dengan wisatawan melalui teknologi. Lansekap terkait sharing economy di dunia pariwisata terdapat pada Gambar 1.

Lanskap tersebut memberikan gambaran peran sharing economy dalam dunia pariwisata, seperti memberikan kemudahan dalam pemenuhan kebutuhan wisatawan akan tempat tinggal, tempat makan, tempat berbelanja, tempat rekreasi, moda transportasi, pelayanan perbankan, bahkan tempat mengembangkan diri. Oleh karena itu, sharing economy dapat dikatakan sebagai sebuat platform/program yang memungkinkan pertukaran informasi dari banyak sumber dapat dilakukan dengan mudah. Pais dan Provasi (2015) menyatakan bahwa sharing economy terbagi ke dalam 6 (enam) jenis, yaitu: rental economy, peer-to-peer economy, on-demand economy, time banking and local exchange trading system, FLOSS-freellibre open source software, dan social lending and crowdfunding (Selloni, 2017).

Enam jenis sharing economy tersebut memiliki perbedaan karakteristik, sebagai berikut: (1) Rental economy umumnya dilakukan oleh perusahaan yang berspesialisasi dalam barang 
seperti pengguna memiliki kepemilikan pribadi eksklusif atas barang tersebut ketika barang tersebut tidak digunakan seperti platform sewa kendaraan Zipcar; (2) Peer-to-peer economy adalah kegiatan ekonomi yang menyangkut barang yang sedang tidak digunakan oleh pemiliknya namun ditawarkan langsung kepada pengguna baru sementara seperti platform Airbnb; (3) On-demand economy, merupakan kegiatan ekonomi yang ditandai oleh platform penggunaan menjadi penengah pada layanan pribadi yang disediakan oleh profesional dan non-profesional seperti Uber, Blablacar, atau Taskrabbit; (4) Time banking and local exchange trading system adalah platform yang mengakomodir kegiatan ekonomi menggunakan bentuk barter dengan menitikberatkan unit layanannya berdasarkan penggunaan mata uang alternatif atau waktu seperti timerepublik; (5) FLOSS merupakan platform yang tertua dari sharing economy yang open source, dimana memberikan pelayanan untuk membagikan program hasil komunitas pengembang dan pengguna tingkat lanjut (Linux) yang sifatnya software bebas atau open source; serta (6) Pinjaman sosial dan crowdfunding adalah platform yang memberikan pelayanan keuangan seperti pinjaman langsung untuk memberikan modal pada pengembang yang potensial dan memiliki ide-ide baru contohnya seperti Kick starter (Saputra \& Hayatin, 2019).

Merujuk pada paragraf sebelumnya, dari 6 (enam) jenis Sharing economy yang sedang berkembang saat ini beberapa di antaranya berkaitan dengan industri pariwisata. Namun, yang berkaitan langsung dengan usaha penyediaan akomodasi merupakan jenis Peer-to-peer economy. Dengan jenis sharing ini, peluang membuka usaha penyediaan akomodasi semakin terbuka sangat lebar, sehingga peluang terjadinya konflik semakin besar. Peer-to-Peer dibagi ke dalam 3 jenis klasifikasi, antara lain: peer-to-peer, business-to-peer, dan beer-to-business-to-peer (Geerts, 2016). Peer-to-peer adalah model platform yang memungkinkan interaksi langsung antara pemilik dan pengguna, atau tuan rumah dan tamu, seperti: Airbnb, HomeAway, VRBO, Wimdu, dan 9Flats (keduanya berbasis di Jerman), Tujia (berbasis di Tiongkok), Homestay, Travelmob, Flipkey, dan Roomorama. Pada model peer-to-peer ini terdapat prinsip pakai-bersama dalam mengkonsumsi barang atau jasa antar individu, yang berarti penyedia barang atau jasa tidak menghasilkan barang atau jasa yang baru (Demary, 2015). Dalam hal ini penyedia barang atau jasa tersebut hanya bertindak sebagai perantara antara permintaan dan penawaran. Sebagai contoh untuk model jenis ini adalah platform yang membawa wisatawan dan pemilik rumah pribadi bersama-sama untuk tujuan menyediakan akomodasi.

Menurut model tersebut, perusahaan yang bergerak di bidang sharing economy memberikan platform pengelolaan. Pengelolaan ini umumnya berkaitan dengan kegiatan pemasaran seperti promosi dan distribusi barang/jasa kepada calon konsumen. Salah satu platform peer-to-peer yang menjadi bahan kajian adalah Airbnb. Meskipun situs web Airbnb merupakan platform peer-topeer accommodation, situs web ini dianggap unik dengan elemen desain visualnya, cara penyampaian informasi yang otentik, dan dapat diandalkan (Akarsu dkk, 2020)

Peer-to-peer economy Airbnb menurut hasil penelitian di beberapa negara di dunia berpengaruh kepada penurunan pendapatan serta keuntungan pengusaha hotel khususnya yang bergerak di Budget Hotel (Akbar \& Tracogna, 2018). Sejumlah penulis berpendapat bahwa Airbnb berperan sebagai substitusi bagi hotel tertentu, sehingga berdampak pada pendapatan hotel (Guttentag \& Smith, 2017). Selain itu, beralihnya konsumen ke Airbnb disebabkan adanya tiga faktor utama, yakni website, layanan yang menarik, dan perceived authenticity (Akarsu dkk, 2020).

Meskipun demikian, platform ini umumnya melanggar undang-undang dan peraturan perumahan setempat, penghindaran terhadap pajak dan deregulasi terhadap pasar tenaga kerja (Selloni, 2017). Keharusan mendaftarkan usaha kepada pemerintah yang kebanyakan dilanggar, menjadi titik tolak konflik antara fenomena peer-to-peer economy dengan usaha penyediaan akomodasi. Bahkan di sejumlah negara, pemerintah mengajukan gugatan dengan tuntutan ganti rugi yang tidak sedikit kepada platform Airbnb. Beberapa kebijakan untuk 
merespon kemunculan platform Airbnb di beberapa negara antara lain: persyaratan izin (Barcelona, Berlin, Paris, San Francisco, dan Los Angeles), membatasi masa sewa (Amsterdam, New York, Paris, dan San Francisco), membayar pajak sewa (Amsterdam dan San Francisco), atau melarang persewaan jangka pendek dalam beberapa kondisi (Berlin dan New York) (GarciaLópez dkk, 2020)

Di Indonesia, peraturan terkait usaha akomodasi tertuang dalam Undang-Undang Nomor 10/2009 tentang Kepariwisataan. Pada pasal 15 ayat 1 tertuang bahwa untuk dapat menyelenggarakan usaha pariwisata, pengusaha kepariwisataan wajib mendaftarkan usahanya terlebih dahulu kepada pemerintah atau pemerintah daerah (Kementerian Hukum dan HAM, 2009). Sementara pemerintah dan pemerintah daerah sesuai Pasal 17 wajib mengembangkan dan melindungi usaha mikro, kecil, menengah, dan koperasi dalam bidang usaha pariwisata dengan cara membuat kebijakan pencadangan usaha pariwisata untuk usaha mikro, kecil, menengah, dan koperasi; dan memfasilitasi kemitraan usaha mikro, kecil, menengah, dan koperasi dengan usaha skala besar (Kementerian Hukum dan HAM, 2009). Lebih lanjut pada pasal 54 dijelaskan bahwa produk, pelayanan, dan pengelolaan usaha pariwisata memiliki standar usaha yang dilakukan melalui sertifikasi usaha. Sertifikasi usaha sebagaimana dimaksud pada pasal 54 tersebut dilakukan oleh lembaga mandiri yang berwenang sesuai dengan ketentuan peraturan perundang-undangan (Kementerian Hukum dan HAM, 2009). Kewajiban Pemerintah sesuai dengan pasal 23 ayat $1 \mathrm{~b}$ adalah menciptakan iklim yang kondusif untuk perkembangan usaha pariwisata yang meliputi terbukanya kesempatan yang sama dalam berusaha, memfasilitasi, dan memberikan kepastian hukum (Kementerian Hukum dan HAM, 2009). Untuk itu, pemerintah perlu melakukan pendataan terkait usaha pariwisata yang ada di wilayahnya. Pada pasal 29 pemerintah provinsi, kabupaten/ kota berwenang melaksanakan pendaftaran, pencatatan, dan pendataan pendaftaran usaha pariwisata (Kementerian Hukum dan HAM, 2009).

\section{METODE PENELITIAN}

Jenis penelitian ini adalah penelitian deskriptif dengan penggabungan metode kuantitatif dan kualitatif. Penelitian deskriptif dimaksudkan untuk mengeksplorasi dan mengklarifikasi suatu fenomena atau kenyataan sosial, dengan cara mendeskripsikan sejumlah variabel yang berkenaan dengan masalah dan unit yang diteliti (Mulyadi, 2011). Beberapa teknik pengumpulan data yang digunakan adalah studi kepustakaan bersumber dari buku serta literatur lainnya baik online maupun offline dan Diskusi Kelompok Terpumpun (DKT) yang bersumber dari hasil pembahasan bersama dengan para pemangku kepentingan yang terkait dengan isu yang dibahas. Menurut Lehoux dkk, (2006), DKT merupakan metode pengumpul data yang dihasilkan dari eksplorasi interaksi sosial yang terjadi dengan para informan yang terlibat yang digunakan oleh jenis penelitian kualitatif (Afiyanti, 2008). Agar lebih efektif, maka jumlah kelompok antara 7-10 orang dan dapat diperbanyak hingga 12 orang, sehingga menjamin kesempatan memberikan pendapat bagi individu untuk memungkinkan memperoleh pandangan yang bervariasi (Paramita \& Kristiana, 2013).

Dalam kajian ini, informan dalam FGD ini dipilih dari unsur-unsur pemerintahan, swasta, dan akademisi. Pemerintah, dalam hal ini adalah Pemerintah Provinsi DKI Jakarta, berperan dalam memberikan pandangan terhadap bagaimana potensi dampak platform ini terhadap penerimaan daerah, serta peraturan-peraturan daerah yang terkait dengan usaha penyediaan akomodasi. Swasta, dalam hal ini adalah Persatuan Hotel dan Restoran Indonesia (PHRI), berperan dalam memberikan gambaran terkait perkembangan usaha penyediaan akomodasi di Provinsi DKI Jakarta, serta potensi dampak yang mungkin terjadi. Sementara akademisi, merupakan mereka yang berkecimpung pada dunia pendidikan, khususnya pendidikan pariwisata dan perhotelan, dalam memberikan gambaran terkait perkembangan platform ini serta potensi dampak pada usaha penyediaan akomodasi.

Untuk mengetahui potensi perkembangan Airbnb maka dilakukan pendekatan dengan metode peramalan. Ramalan (forecast) merupakan dugaan, perkiraan, atau prediksi terhadap kejadian 
atau peristiwa di masa yang akan datang. Peramalan merupakan alat bantu yang penting dalam perencanaan yang efektif dan efisien, yang digunakan dalam kondisi tersedianya informasi masa lalu yang dapat dikuantifikatifkan dalam bentuk data numerik, dan dapat diasumsikan bahwa beberapa aspek pola masa lalu akan berlanjut dimasa yang akan datang (Makridakis dkk., 1997). Secara prinsip, data deret waktu digunakan untuk memprediksi masa depan menggunakan data berdasarkan deret waktu sebelumnya (Haviluddin dkk., 2016) . Data deret waktu adalah jenis kumpulan data yang terurut dalam waktu dan bersifat historical. Sedangkan yang akan menjadi variabel peramalan ini adalah Tingkat Penghunian Kamar (TPK), yang menurut Badan Pusat Statistik (2017) berarti perbandingan antara banyaknya malam kamar yang terpakai dengan banyaknya malam kamar yang tersedia dalam persen (Badan Pusat Statistik, 2020). Tingkat hunian kamar merupakan salah satu indikator kesuksesan usaha penyediaan. Semakin tinggi tingkat hunian berarti semakin banyak jumlah kamar yang terjual.

Metode peramalan yang digunakan adalah single exponential smoothing dan winter additive exponential smoothing sesuai dengan karakteristik data. Exponential smoothing adalah salah satu metode peramalan yang sering digunakan karena lebih sederhana, mudah menyesuaikan respon terhadap perubahan dan memiliki akurasi yang wajar (Raihan dkk., 2016). Single exponential smoothing setelah melihat karakteristik data yaitu tidak ditemukan adanya trend dan pola musiman dari data (Rachmat \& Suhartono, 2020; Sbrana \& Silvestrini, 2014). Rumus dari peramalan tersebut adalah

$\hat{Y}_{t+1}=\alpha Y_{t}+(1-\alpha) \hat{Y}_{t}$

di mana

$\hat{Y}_{t+1}=$ nilaiperamalan pada periode selanjutnya atau periode ke- $\mathrm{t}+1$

$Y_{t}=$ nilai riil dari data periode ke- $\mathrm{t}$

$\hat{Y}_{t}=$ nilai peramalan pada periode ke- $\mathrm{t}$
Sedangkan metode winters additive exponential smoothing digunakan karena data memiliki komponen level, komponen trend, dan komponen musiman (Dewi \& Listiowarni, 2020). Model ini dapat tersusun dari tiga rangkaian proses statistik yang terkorelasi (pemulusan, trend, dan musiman) dan memproyeksikan trend serta komponen musiman ke depan. Rumusnya adalah

$L_{t}=\alpha\left(Y_{t}-S_{t-s}\right)+(1-\alpha)\left(L_{t-1}+b_{t-1}\right)$

$b_{t}=\beta\left(L_{t}-L_{t-1}\right)+(1-\beta) b_{t-1}\left(L_{t-1}+b_{t-1}\right)$

$S_{t}=\gamma\left(Y_{t}-L_{t}\right)+(1-\gamma) S_{t-s}$

$\hat{Y}_{t-m}=L_{t}+b_{t} m+S_{t-s+m}$

di mana

$Y_{t} \quad=$ nilai riil pada periode ke- $\mathrm{t}$

$L_{t} \quad=$ nilai level pada periode $\mathrm{ke}-\mathrm{t}$

$L_{t-1}=$ nilai level pada periode ke- $\mathrm{t}-1$

$b_{t} \quad=$ nilai trend pada periode ke- $\mathrm{t}-$

$b_{t-1}=$ nilai trend pada periode ke- $\mathrm{t}-1$

$S_{t} \quad=$ nilai seasonal pada periode ke- $\mathrm{t}$

$S_{t-s}=$ pemulusan faktor musiman

$\alpha=$ konstanta pembobot level $(0<\alpha<1)$

$\beta=$ konstanta pembobot trend $(0<\beta<1)$

$\gamma=$ konstanta pembobot musiman $(0<\gamma<1)$

$s \quad=$ panjang musiman $\left({ }^{S}=12\right)$

$t=$ periode musiman

$m$ = periode waktu yang diramalkan

$\hat{Y}_{t-m}=$ hasil peramalan ke- $\mathrm{t}+\mathrm{m}$

Kemudian untuk melihat model yang terbaik maka dilakukan perhitungan nilai kebaikan model dengan Mean Absolute Percent (MAPE) dan Root Mean Square (RMSE). Semakin kecil nilai MAPE dan RMSE maka tingkat akurasi dari peramalan semakin baik. Rumus perhitungan MAPE adalah sebagai berikut

$$
\begin{aligned}
& M A P E=\frac{1}{n} \sum_{t=1}^{n}\left|\frac{Y_{t}-\hat{Y}_{t}}{Y_{t}}\right| \times 100 \% \\
& R M S E=\sqrt{\frac{\sum_{t=1}^{n}\left(Y_{t}-\hat{Y}_{t}\right)^{2}}{n}}
\end{aligned}
$$

di mana

$Y_{t} \quad=$ nilai riil dari data periode ke- $\mathrm{t}$

$\hat{Y}_{t}=$ nilai peramalan pada periode ke- $\mathrm{t}$

$n$ = banyaknya data 


\section{HASIL DAN PEMBAHASAN}

\section{Perkembangan Usaha Penyedia Jasa Akomodasi di Provinsi DKI Jakarta}

Pertumbuhan sektor ini juga terlihat dari jenis usaha penyediaan akomodasi yang terus meningkat setiap tahunnya. Tercatat di tahun 2016 lalu terdapat 437 usaha hotel baik yang berbintang maupun non-bintang, dengan 48.104 kamar dan 66.284 jumlah tempat tidur yang tersedia di kota ini. Sejak tahun 2010 lalu, ratarata muncul sebanyak 12 usaha akomodasi baru di Kota Jakarta, dengan penambahan rata-rata kamar sebanyak 1.798 pertahun dan rata-rata penambahan tempat tidur sebanyak 2.484 per tahun (Badan Pusat Statistik Provinsi DKI Jakarta, 2011, 2012, 2013, 2014, 2015, 2016, 2017).

Tidak hanya dari segi jumlah usaha yang bertambah, pendapatan daerah dari pajak usaha hotel juga ikut bertambah. Pada tahun 2016 lalu, jumlah realisasi pajak hotel kota Jakarta tercatat sebesar Rp3,9 triliun, naik dari tahun sebelumnya yang tercatat sebesar Rp3,5 triliun. Namun, yang menarik, meskipun jumlah realisasi pajak hotel terus meningkat setiap tahunnya, hal ini berbanding terbalik dengan tingkat kontribusi pajak hotel terhadap total pajak daerah keseluruhan. Jika di tahun 2010 lalu kontribusi pajak hotel tercatat sebesar $15,12 \%$, di tahun
2016 tercatat hanya sebesar 12,51\% (Badan Pusat Statistik Provinsi DKI Jakarta, 2011, 2012, 2013, 2014, 2015, 2016, 2017).

Pada Tabel 1 juga terlihat bahwa jumlah tamu asing yang menginap di hotel pada tahun 2016 tercatat sejumlah 56.679 orang, naik 120,9\% dibandingkan tahun sebelumnya, sedangkan jumlah tamu lokal yang menginap di hotel tahun 2016 tercatat sejumlah 3.175.019 atau naik sebesar $124,1 \%$ dibandingkan dengan tahun sebelumnya. Secara total jumlah tamu yang menginap di hotel tahun 2016 tercatat sejumlah 3.231 .698 orang atau naik sebesar $124,0 \%$ dibandingkan tahun sebelumnya.

Menurut pendataan yang dilakukan oleh Badan Pusat Statistik (BPS), jumlah kunjungan wisatawan mancanegara (wisman) yang melalui pintu masuk Bandara Internasional SoekarnoHatta meningkat setiap tahunnya. Pada tahun 2017 lalu, sebanyak 2,56 juta wisatawan mancanegara tercatat mengunjungi Indonesia melalui pintu masuk ini dengan tingkat pertumbuhan 6,09\% dibandingkan tahun sebelumnya (Badan Pusat Statistik, 2018) .

Tabel 1. Perkembangan Jumlah Tamu yang Menginap di Hotel di Kota Jakarta Tahun 2010--2016

\begin{tabular}{lllllll}
\hline Periode & WNA & WNI & TOTAL & + - WNA & $+/$ - WNI & $+/$ - TOTAL \\
\hline 2010 & 12,815 & $1,478,187$ & $1,491,002$ & $-1.8 \%$ & $32.4 \%$ & $32.0 \%$ \\
\hline 2011 & 55,737 & $2,428,937$ & $2,484,675$ & $334.9 \%$ & $64.3 \%$ & $66.6 \%$ \\
\hline 2012 & 44,448 & $2,223,323$ & $2,267,772$ & $-20.3 \%$ & $-8.5 \%$ & $-8.7 \%$ \\
\hline 2013 & 44,246 & $2,918,151$ & $2,962,397$ & $-0.5 \%$ & $31.3 \%$ & $30.6 \%$ \\
\hline 2014 & 178,954 & $4,788,478$ & $4,967,432$ & $304.5 \%$ & $64.1 \%$ & $67.7 \%$ \\
\hline 2015 & 25,655 & $1,416,859$ & $1,442,514$ & $-85.7 \%$ & $-70.4 \%$ & $-71.0 \%$ \\
\hline 2016 & 56,679 & $3,175,019$ & $3,231,698$ & $120.9 \%$ & $124.1 \%$ & $124.0 \%$ \\
\hline
\end{tabular}

Sumber: Badan Pusat Statistik, diolah lagi oleh penulis

Keterangan: WNA (Warga Negara Asing), WNI (Warga Negara Indonesia). 
Tabel 2. Profil Wisman pada Pintu Masuk Bandara Internasional Soekarno-Hatta Tahun 2015

\begin{tabular}{lll}
\hline Kriteria & \multicolumn{2}{l}{ Indikator } \\
\hline \multirow{4}{*}{ Maksud dan Tujuan } & $\begin{array}{l}\text { Bisis dan Meeting, Incentive, Convention, \& Exhibition } \\
\text { (MICE) }\end{array}$ & $47,06 \%$ \\
\cline { 2 - 3 } & Liburan & $35,57 \%$ \\
\cline { 2 - 3 } & Mengunjungi Teman/Keluarga & $11,44 \%$ \\
\cline { 2 - 3 } Pilihan Akomodasi & Lainnya & $5,93 \%$ \\
\cline { 2 - 3 } & Hoter Bintang & $72,40 \%$ \\
\cline { 2 - 3 } & Rumah Teman/Keluarga & $11,70 \%$ \\
\cline { 2 - 3 } & Hotel Non Bintang & $8,39 \%$ \\
\hline Rata-Rata Pengeluaran / Kunjungan & 7,51 \\
\hline Rata-Rata Lama Tinggal & & $\mathrm{USD} 791,05$ \\
\hline
\end{tabular}

Sumber: Hidayah dan Utami (2015)

Tabel 3. Profil Wisatawan Nusantara Tahun 2017

\begin{tabular}{lll}
\hline Kriteria & \multicolumn{2}{l}{ Indikator } \\
\hline \multirow{3}{*}{ Maksud dan Tujuan } & \multicolumn{1}{l}{ Berlibur } & $39,35 \%$ \\
\cline { 2 - 3 } & Mengunjungi Teman/Keluarga & $39,29 \%$ \\
\cline { 2 - 3 } & \multicolumn{1}{l}{ Bisnis, Pertemuan, Kongres, Seminar } & $9,65 \%$ \\
\cline { 2 - 3 } Pilihan Akomodasi & Lainnya & $11,71 \%$ \\
\cline { 2 - 3 } & Rumah Teman/Keluarga & $61,02 \%$ \\
\cline { 2 - 3 } & Hotel & $30,77 \%$ \\
\cline { 2 - 3 } & Lkomodasi Komersial Lainnya & $6,87 \%$ \\
\hline Rata-Rata Pengeluaran / Kunjungan & & $1,34 \%$ \\
\hline Rata-Rata Lama Tinggal & & Rp. 4.374.590 \\
\hline
\end{tabular}

Sumber: Badan Pusat Statistik \& Kementerian Pariwisata (2017)

Terjadi perbedaan yang sangat signifikan antara data BPS terkait jumlah tamu asing yang menginap di hotel, dengan jumlah wisman yang memilih untuk menginap di hotel berbintang. Data BPS menunjukkan bahwa jumlah tamu asing yang menginap di hotel selama setahun berkisar pada angka 50 ribu tamu, hal ini berbeda dengan potensi wisman yang lebih dari $70 \%$ menggunakan hotel sebagai tempat menginap seperti yang terlihat pada Tabel 2. Kunjungan melalui Bandara International Soekarno-Hatta yang merupakan pintu masuk internasional menuju Jakarta, didominasi oleh wisman yang berkunjung dengan maksud dan tujuan Bisnis dan MICE. Sedangkan jumlah perjalanan wisatawan nusantara (wisnus) yang melakukan perjalanan ke Provinsi DKI Jakarta pada tahun 2017 lalu tercatat sebanyak 15,7 juta perjalanan atau meningkat $13,99 \%$ dari tahun sebelumnya (Badan Pusat Statistik \& Kementerian Pariwisata, 2017). Sedangkan menurut survei wisnus yang dilakukan
BPS di tahun 2017 lalu, didapatkan profil wisnus yang berkunjung ke DKI Jakarta terdapat pada Tabel 3.

Hasil survei pada Tabel 3 menunjukkan bahwa rata-rata pengeluaran wisnus yang datang ke Provinsi DKI jakarta adalah sebesar Rp4,4 juta dengan rata-rata lama kunjungan selama 6,18 hari. Jika melihat maksud dan tujuan, paling banyak melakukan perjalanan untuk mengunjungi teman/ keluarga sebesar 39,29\%, diikuti dengan berlibur/ rekreasi sebesar 39,35\%. Jika mengunjungi teman/ keluarga dan berekreasi menjadi tujuan utama, maka mayoritas dari wisnus menggunakan sarana akomodasi berupa menginap di Rumah Teman/ Keluarga menjadi pilihan utama dengan $61,02 \%$, sementara menginap di hotel dan akomodasi lainnya sebesar $37,64 \%$. Hal ini menunjukkan bahwa lebih dari sepertiga perjalanan yang dilakukan wisnus yang datang ke Provinsi DKI Jakarta menggunakan jenis akomodasi komersial baik hotel maupun akomodasi lainnya. Terjadi 
perbedaan yang sangat signifikan antara data BPS terkait jumlah tamu berkewarganegaraan Indonesia (WNI) yang menginap di hotel, dengan jumlah wisnus yang memilih untuk menginap di hotel. Data BPS menunjukkan bahwa jumlah tamu WNI yang menginap di hotel selama setahun berkisar pada angka 3 juta tamu, hal ini berbeda dengan potensi wisnus yang lebih dari sepertiganya memilih untuk menggunakan hotel sebagai tempat menginap, atau jika diasumsikan sebesar 5,3 juta.

Berdasarkan kepada hasil FGD, disampaikan bahwa kondisi pertumbuhan hotel di Jakarta saat ini tumbuh sangat pesat. Meskipun tidak dapat menunjukkan data eksplisit, PHRI mendeskripsikan bahwa, hingga saat ini masih banyak hotel dan sarana akomodasi lain yang akan berdiri di Jakarta. Hal ini didasari dengan banyaknya permintaan pada jenis usaha ini. Hampir seluruh usaha akomodasi yang beroperasi di DKI Jakarta memfokuskan diri kepada pasar bisnis dan grup yang berasal dari pemerintah dan swasta. Jumlah kamar yang banyak, menuntut pengusaha akomodasi untuk menggarap pasar ini lebih dari pasar individual. Oleh karena itu, ketika pemerintah pada tahun lalu menghimbau untuk membatasi penggunaan hotel untuk acara meeting, dan pertemuan lainnya, memberikan dampak yang sangat dirasakan oleh pengusaha hotel saat itu. Ini menjadi bukti bahwa ketergantungan atas pangsa pasar bisnis dan grup sangat tinggi.

\section{Perkembangan Platform Peer-To-Peer Economy Airbnb di Provinsi DKI Jakarta}

Tempat-tempat di Airbnb dikategorikan sesuai tipe tempat berikut (Airbnb, 2020a):

1. Seluruh tempat/entire home: Tamu dapat menggunakan seluruh tempat sepenuhnya untuk mereka sendiri. Ini biasanya termasuk kamar tidur, kamar mandi, dan dapur.

2. Kamar pribadi/private room: Tamu akan mendapatkan ruang tidur pribadi. Ruangan lainnya mungkin digunakan bersama.

3. Kamar bersama/shared room: Tamu tidur di kamar tidur atau area umum yang mungkin digunakan bersama dengan tamu atau penghuni lain.

Tabel 4. Perkembangan Jumlah Listing Airbnb di Provinsi DKI Jakarta

\begin{tabular}{|c|c|c|c|c|c|c|c|c|c|}
\hline \multirow{2}{*}{ Periode } & & \multicolumn{4}{|c|}{ Jumlah Listing } & \multicolumn{4}{|c|}{ Pertumbuhan Listing } \\
\hline & & $\begin{array}{l}\text { Entire } \\
\text { Home }\end{array}$ & $\begin{array}{l}\text { Private } \\
\text { Room }\end{array}$ & $\begin{array}{l}\text { Shared } \\
\text { Room }\end{array}$ & Total & $\begin{array}{l}\text { Entire } \\
\text { Home }\end{array}$ & $\begin{array}{l}\text { Private } \\
\text { Room }\end{array}$ & $\begin{array}{l}\text { Shared } \\
\text { Room }\end{array}$ & Total \\
\hline \multirow{5}{*}{2015} & Ags & 564 & 385 & 17 & 966 & & & & \\
\hline & Sep & 633 & 432 & 16 & 1.081 & $12,23 \%$ & $12,21 \%$ & $-5,88 \%$ & $11,90 \%$ \\
\hline & Okt & 648 & 438 & 17 & 1.103 & $2,37 \%$ & $1,39 \%$ & $6,25 \%$ & $2,04 \%$ \\
\hline & Nov & 708 & 489 & 19 & 1.216 & $9,26 \%$ & $11,64 \%$ & $11,76 \%$ & $10,24 \%$ \\
\hline & Des & 769 & 551 & 21 & 1.341 & $8,62 \%$ & $12,68 \%$ & $10,53 \%$ & $10,28 \%$ \\
\hline \multirow{12}{*}{2016} & Jan & 828 & 632 & 21 & 1.481 & $7,67 \%$ & $14,70 \%$ & $0,00 \%$ & $10,44 \%$ \\
\hline & Feb & 896 & 655 & 19 & 1.570 & $8,21 \%$ & $3,64 \%$ & $-9,52 \%$ & $6,01 \%$ \\
\hline & Mar & 952 & 649 & 23 & 1.624 & $6,25 \%$ & $-0,92 \%$ & $21,05 \%$ & $3,44 \%$ \\
\hline & Apr & 848 & 542 & 24 & 1.414 & $-10,92 \%$ & $-16,49 \%$ & $4,35 \%$ & $-12,93 \%$ \\
\hline & Mei & 904 & 629 & 27 & 1.560 & $6,60 \%$ & $16,05 \%$ & $12,50 \%$ & $10,33 \%$ \\
\hline & Jun & 857 & 536 & 22 & 1.415 & $-5,20 \%$ & $-14,79 \%$ & $-18,52 \%$ & $-9,29 \%$ \\
\hline & Jul & 1.199 & 856 & 30 & 2.085 & $39,91 \%$ & $59,70 \%$ & $36,36 \%$ & $47,35 \%$ \\
\hline & Ags & 1.380 & 947 & 31 & 2.358 & $15,10 \%$ & $10,63 \%$ & $3,33 \%$ & $13,09 \%$ \\
\hline & Sep & 1.436 & 980 & 36 & 2.452 & $4,06 \%$ & $3,48 \%$ & $16,13 \%$ & $3,99 \%$ \\
\hline & Okt & 1.589 & 1.065 & 42 & 2.696 & $10,65 \%$ & $8,67 \%$ & $16,67 \%$ & $9,95 \%$ \\
\hline & Nov & 1.589 & 1.068 & 44 & 2.701 & $0,00 \%$ & $0,28 \%$ & $4,76 \%$ & $0,19 \%$ \\
\hline & Des & 1.658 & 1.096 & 49 & 2.803 & $4,34 \%$ & $2,62 \%$ & $11,36 \%$ & $3,78 \%$ \\
\hline
\end{tabular}




\begin{tabular}{|c|c|c|c|c|c|c|c|c|c|}
\hline \multirow{2}{*}{ Periode } & & \multicolumn{4}{|c|}{ Jumlah Listing } & \multicolumn{4}{|c|}{ Pertumbuhan Listing } \\
\hline & & $\begin{array}{l}\text { Entire } \\
\text { Home }\end{array}$ & $\begin{array}{l}\text { Private } \\
\text { Room }\end{array}$ & $\begin{array}{l}\text { Shared } \\
\text { Room }\end{array}$ & Total & $\begin{array}{l}\text { Entire } \\
\text { Home }\end{array}$ & $\begin{array}{l}\text { Private } \\
\text { Room }\end{array}$ & $\begin{array}{l}\text { Shared } \\
\text { Room }\end{array}$ & Total \\
\hline \multirow{12}{*}{2017} & Jan & 1.703 & 1.096 & 50 & 2.849 & $2,71 \%$ & $0,00 \%$ & $2,04 \%$ & $1,64 \%$ \\
\hline & Feb & 1.607 & 1.015 & 50 & 2.672 & $-5,64 \%$ & $-7,39 \%$ & $0,00 \%$ & $-6,21 \%$ \\
\hline & Mar & 1.858 & 1.129 & 60 & 3.047 & $15,62 \%$ & $11,23 \%$ & $20,00 \%$ & $14,03 \%$ \\
\hline & Apr & 1.806 & 1.043 & 66 & 2.915 & $-2,80 \%$ & $-7,62 \%$ & $10,00 \%$ & $-4,33 \%$ \\
\hline & Mei & 2.156 & 1.258 & 73 & 3.487 & $19,38 \%$ & $20,61 \%$ & $10,61 \%$ & $19,62 \%$ \\
\hline & Jun & 2.258 & 1.311 & 75 & 3.644 & $4,73 \%$ & $4,21 \%$ & $2,74 \%$ & $4,50 \%$ \\
\hline & Jul & 2.378 & 1.324 & 80 & 3.782 & $5,31 \%$ & $0,99 \%$ & $6,67 \%$ & $3,79 \%$ \\
\hline & Ags & 2.433 & 1.355 & 81 & 3.869 & $2,31 \%$ & $2,34 \%$ & $1,25 \%$ & $2,30 \%$ \\
\hline & Sep & 2.562 & 1.376 & 81 & 4.019 & $5,30 \%$ & $1,55 \%$ & $0,00 \%$ & $3,88 \%$ \\
\hline & Okt & 2.715 & 1.408 & 81 & 4.204 & $5,97 \%$ & $2,33 \%$ & $0,00 \%$ & $4,60 \%$ \\
\hline & Nov & 2.779 & 1.421 & 83 & 4.283 & $2,36 \%$ & $0,92 \%$ & $2,47 \%$ & $1,88 \%$ \\
\hline & Des & 2.911 & 1.460 & 83 & 4.454 & $4,75 \%$ & $2,74 \%$ & $0,00 \%$ & $3,99 \%$ \\
\hline \multirow{7}{*}{2018} & Jan & 2.908 & 1.469 & 82 & 4.459 & $-0,10 \%$ & $0,62 \%$ & $-1,20 \%$ & $0,11 \%$ \\
\hline & Feb & 2.996 & 1.508 & 83 & 4.587 & $3,03 \%$ & $2,65 \%$ & $1,22 \%$ & $2,87 \%$ \\
\hline & Mar & 3.108 & 1.575 & 87 & 4.770 & $3,74 \%$ & $4,44 \%$ & $4,82 \%$ & $3,99 \%$ \\
\hline & Apr & 3.211 & 1.590 & 87 & 4.888 & $3,31 \%$ & $0,95 \%$ & $0,00 \%$ & $2,47 \%$ \\
\hline & Mei & 3.260 & 1.577 & 84 & 4.921 & $1,53 \%$ & $-0,82 \%$ & $-3,45 \%$ & $0,68 \%$ \\
\hline & Jun & 3.551 & 1.595 & 81 & 5.227 & $8,93 \%$ & $1,14 \%$ & $-3,57 \%$ & $6,22 \%$ \\
\hline & Jul & 3.738 & 1.668 & 88 & 5.494 & $5,27 \%$ & $4,58 \%$ & $8,64 \%$ & $5,11 \%$ \\
\hline \multicolumn{6}{|c|}{ Rata-rata Pertumbuhan Perbulan } & $5,39 \%$ & $4,16 \%$ & $4,67 \%$ & $4,95 \%$ \\
\hline
\end{tabular}

Sumber: Hasil olahan Penulis (2020)

Tabel 5. Jenis dan Jumlah Pemilik Aktif Listing Airbnb di Provinsi DKI Jakarta

\begin{tabular}{lll}
\hline Jenis Kepemilikan & Jumlah & \% \\
\hline Multi-listing Hosts & 696 & 18,74 \\
\hline Single-listing Hosts & 3.018 & 81,26 \\
\hline Total & 3.714 & 100,00 \\
\hline
\end{tabular}

Sumber: Hasil olahan Penulis (2020)

Jika dilihat pada Tabel 4, dalam kurun waktu tiga tahun, platform Airbnb tumbuh pesat, dari 966 listing di DKI Jakarta yang tercatat pada periode Agustus 2015 meningkat menjadi 5.494 listing pada Juli 2018. Pertumbuhan rata-rata selama periode Agustus 2015 hingga Juli 2018 lalu tercatat sebesar 4,95\%. Dari keseluruhan listing yang ada, yang paling banyak adalah yang tergolong ke dalam Entire Home sebanyak 3.738, diikuti oleh 1.668 listing Private Room dan 88 listing Shared Room pada bulan Juli 2018 lalu. Dari Tabel 5 apabila dilihat dari segi kepemilikannya, sebanyak $81 \%$ yang terdaftar sebagai kepemilikan aktif 1 listing per orang sementara, 19\% sisanya terdaftar dengan kepemilikan lebih dari 1 listing.

\section{Potensi Dampak Kemunculan Peer-to- Peer Economic Platform Airbnb terhadap Usaha Penyediaan Akomodasi di Provinsi DKI Jakarta}

Untuk menjawab permasalahan dalam penelitian ini, penulis melakukan peramalan terhadap variabel tingkat penghunian kamar hotel bintang dan nonbintang dengan tingkat penghunian kamar Airbnb entire home, private room, dan shared room. Hal tersebut untuk mengetahui seberapa 
jauh okupansi dari Airbnb akan memengaruhi okupansi hotel bintang dan nonbintang. Adapun data yang diperoleh dari publikasi Statistik Hotel dan Tingkat Penghunian Kamar Hotel DKI Jakarta 2011-2016 serta berita resmi statistik Tingkat Penghunian Kamar (TPK) Hotel Berbintang DKI Jakarta tahun 2017 hingga bulan Juli tahun 2018, BPS Provinsi DKI Jakarta.

Pada Appendix 1, menunjukkan bahwa tingkat hunian kamar hotel bintang dan nonbintang sebagian besar bulannya mengalami penurunan pada tahun 2012, 2014, dan 2016. Jika dibandingkan dalam periode yang sama tahun 2015-2018, maka entire home memiliki rentang tingkat hunian sebesar $25,0 \%-46,9 \%$, Private Room memiliki rentang tingkat hunian sebesar 15,1\%-27,0\%, dan shared room memiliki rentang tingkat hunian sebesar $5,3 \%-36,0 \%$. Sedangkan hotel bintang memiliki rentang tingkat hunian sebesar $51,1 \%-78,8 \%$, dan hotel nonbintang memiliki rentang tingkat hunian sebesar $60,5 \%-86,6 \%$. Ini menunjukkan tingkat hunian untuk hotel bintang dan non-bintang masih lebih tinggi dibandingkan platform Airbnb.

Dari data-data sebelumnya dilakukan analisis deret waktu untuk mengetahui pada periode bulan maupun tahun okupansi dari Airbnb akan memengaruhi eksistensi tingkat penghunian hotel bintang dan nonbintang. Dengan menggunakan bantuan perangkat lunak IBM SPSS Versi 21 diperoleh keluaran seperti ditampilkan pada Tabel 6.

Pada Tabel 6 terlihat bahwa, hasil peramalan untuk data tingkat penghunian kamar baik akomodasi berupa hotel maupun Airbnb. Semakin kecil nilai MAPE dan RMSE mengartikan semakin tinggi tingkat akurasi. Selain itu untuk melihat signifikansi model, digunakan uji Ljung box. Pengujian ini menguji kelayakan model peramalan dengan melihat ada tidaknya korelasi serial atau white noise pada nilai eror yang dihasilkan model. Hasil perhitungan untuk Hotel Bintang dapat diidentifikasi dengan nilai MAPE $=4,574, \mathrm{RMSE}=3,950$ dan $\mathrm{R}^{2}=77,8 \%$ yang dapat diartikan model dapat menjelaskan variasi data series sebesar $77,8 \%$ serta semakin kecil nilai MAPE dan RMSEA maka semakin baik tingkat akurasi peramalan. Kemudian jika dilihat nilai signifikansi Ljung Box $(0,424)$ yang lebih besar dibandingkan nilai $p$-value $(0,05)$, dapat diartikan tidak ada korelasi serial atau white noise sehingga model dapat digunakan untuk menduga data tingkat penghunian kamar Hotel Bintang. Untuk data tingkat penghunian kamar Hotel Non Bintang memiliki nilai $\mathrm{MAPE}=6,936$, $\mathrm{RMSE}=6,656$ dan $\mathrm{R}^{2}=59,4 \%$ yang dapat diartikan model dapat menjelaskan variasi data series sebesar 59,4\%. Nilai signifikansi Ljung Box $(0,233)$ yang lebih besar dibandingkan nilai $p$-value $(0,05)$, dapat diartikan tidak ada korelasi serial atau white noise sehingga model dapat digunakan untuk menduga data tingkat penghunian kamar hotel non-bintang.

Selain itu, hasil peramalan untuk data tingkat penghunian kamar Airbnb entire home memiliki nilai MAPE $=5,039$ dan $\mathrm{R}^{2}=79,8 \%$ yang dapat diartikan model dapat menjelaskan variasi data series sebesar 79,8\%. Kemudian jika dilihat nilai signifikansi Ljung Box $(0,108)$ yang lebih besar dibandingkan nilai p-value $(0,05)$, dapat diartikan tidak ada korelasi residual antar lag-nya sehingga

Tabel 6. Hasil Peramalan Tingkat Hunian Kamar

\begin{tabular}{llllll}
\hline Tingkat Penghunian Kamar & MAPE & RMSE & $\mathrm{R}^{2}(\%)$ & $\begin{array}{l}\text { Signifikansi } \\
\text { Ljung Box }\end{array}$ & Keterangan* \\
\hline Hotel Bintang & 4,574 & 3,950 & 77,8 & 0,424 & Signifikan \\
\hline Hotel Non Bintang & 6,936 & 6,656 & 59,4 & 0,233 & Signifikan \\
\hline Airbnb Entire Home & 5,039 & 2,541 & 79,8 & 0,108 & Signifikan \\
\hline Airbnb Private Room & 5,588 & 1,453 & 65,8 & 0,112 & Signifikan \\
\hline Airbnb Shared Room & 39,411 & 6,895 & 62,6 & 0,188 & Signifikan \\
\hline
\end{tabular}

Keterangan: *) Sig. > 0,05

Sumber: Hasil Pengolahan SPSS 21 oleh Penulis (2018) 
model tepat digunakan untuk menduga data tingkat penghunian kamar Airbnb entire home. Kemudian untuk jenis Airbnb private room hasil perhitungan memperlihatkan nilai $\mathrm{MAPE}=5,588$, RMSE $=1,453$ dan $\mathrm{R}^{2}=65,8 \%$ yang dapat diartikan model dapat menjelaskan variasi data series sebesar $65,8 \%$. Kemudian jika dilihat nilai signifikansi Ljung Box $(0,112)$ yang lebih besar dibandingkan nilai $p$-value $(0,05)$, menyimpulkan tidak adanya korelasi residual antar lag-nya sehingga model dapat digunakan untuk menduga data tingkat penghunian kamar Airbnb private room. Pada data tingkat penghunian kamar Airbnb shared room menghasilkan nilai MAPE $=39,411$, $\mathrm{RMSE}=6,895$ dan $\mathrm{R}^{2}=62,6 \%$ yang berarti model dapat menjelaskan variasi data series sebesar $62,6 \%$. Kemudian jika dilihat nilai signifikansi Ljung Box $(0,188)$ yang lebih besar dibandingkan nilai p-value $(0,05)$, menjelaskan bahwa tidak ada korelasi residual antar lag-nya sehingga model dapat digunakan untuk menduga data tingkat penghunian kamar Airbnb shared room.

Dari hasil peramalan tersebut, didapatkan asumsi potensi dampak platform Airbnb terhadap usaha penyediaan akomodasi sebagai berikut. Pertama, pada Appendix 2, tingkat penghunian Kamar Hotel Bintang di Provinsi DKI Jakarta akan mulai terpengaruhi dengan keberadaan Airbnb entire home terhitung pada periode Juni 2023, dan perbedaan terlihat semakin signifikan pada November 2025. Dilihat dengan nilai TPK Airbnb entire home pada periode tersebut lebih tinggi atau berhimpitan dengan TPK Hotel Bintang di Provinsi DKI Jakarta. Hal ini didasarkan karena trend positif kenaikan hunian kamar Airbnb entire home lebih besar dibandingkan kenaikan hunian kamar hotel bintang. Ini mengindikasikan bahwa adanya potensi industri Hotel Bintang mulai tergantikan dengan keberadaan Airbnb entire home. Adapun sebagai catatan tambahan kondisi tersebut terjadi baru memperhitungkan variabel TPK, dengan mengasumsikan variabel lainnya bersifat konstan. Pertumbuhan jumlah listing Airbnb entire home hingga Juni 2018 cukup tinggi yaitu sebesar 5,39\% (CAGR dari Agustus 2015) dan rata-rata tingkat okupansi selama periode tersebut ialah $46,41 \%$. Sehingga dikhawatirkan akan mengerus pasar industri Hotel Bintang di Provinsi DKI Jakarta dan diperlukan rekomendasi dari pemerintah yang dapat menjaga persaingan usaha yang kondusif.

Kedua, pada Appendix 3, Tingkat Penghunian Kamar Hotel Non Bintang di Provinsi DKI Jakarta akan mulai terpengaruhi dengan keberadaan Airbnb entire home terhitung pada periode April 2023. Dengan cara yang sama dengan melihat nilai TPK Airbnb entire home pada periode tersebut berhimpitan dengan TPK Hotel Non Bintang di Provinsi DKI Jakarta. Artinya diproyeksikan nilai TPK Airbnb entire home akan lebih tinggi dibandingkan dengan TPK Hotel Non Bintang. Hal tersebut mengindikasikan bahwa adanya potensi industri Hotel Non Bintang mulai tergantikan dengan keberadaan Airbnb entire home. Berkaca dengan kondisi yang sama dengan kondisi TPK Hotel Bintang yang suatu saat akan tergantikan oleh ketersediaan Airbnb entire home diperlukan rekomendasi dari pemerintah yang dapat menjaga persaingan usaha yang kondusif antara penyedia akomodasi secara konvensional dengan penyedia akomodasi secara digital. Temuan pertama dan kedua tersebut, menegaskan kembali pernyataan dari Akbar \& Tracogna (2018), bahwa Airbnb akan memiliki dampak pada pengusaha hotel khususnya yang bergerak di Budget Hotel. Ketiga, pada Appendix 4, menunjukkan bahwa hasil simulasi pada Hotel Bintang dan Non Bintang dengan Airbnb private room dan shared room, apabila dengan kondisi yang sama atau tidak mengalami banyak perubahan baik kondisi yang bersifat internal maupun eksternal dari usaha penyediaan akomodasi serta Airbnb, maka belum ditemukan potensi dampak singgungan tingkat penghunian kamar Airbnb untuk kedua tipe ini terhadap usaha penyediaan akomodasi.

Sementara menurut perwakilan PHRI, potensi dampak platform ini terhadap usaha penyediaan akomodasi yaitu akan memunculkan persaingan yang tidak sehat. Hal ini didasari dengan belum adanya payung hukum jelas yang menyangkut pada pengelolaan jenis usaha akomodasi yang menggunakan platform tersebut. Jika dibiarkan, tentu ini akan dapat menghancurkan jenis usaha akomodasi, salah satunya adalah hotel. Perwakilan dari Provinsi DKI Jakarta menambahkan, bahwa hingga saat ini pengawasan terhadap jenis platform ini terus dilakukan. Namun, keseluruhan 
peserta FGD sepakat bahwa pengaturan platform ini harus disusun dengan hati-hati.

Platform ini memiliki kemungkinan untuk diterapkan bagi daerah yang memiliki keterbatasan supply sarana akomodasi, sehingga dapat membantu wisatawan dalam menemukan tempat tinggal saat berwisata. Namun, bagi daerah yang dirasakan sudah memiliki pasokan sarana akomodasi yang memadai, tentu platform ini akan sangat merugikan. Hal ini menjadi fokus penting karena masih belum adanya kepastian hukum yang jelas tentang pengelolaan, baik dalam hal kepemilikan, serta hak dan kewajiban pengusaha.

\section{Potensi Dampak Kemunculan Platform Peer-to-Peer Economy Airbnb terhadap Penerimaan Pajak Provinsi DKI Jakarta}

Untuk dapat menghitung potensi dampak Airbnb terhadap potensi penerimaan pajak Provinsi DKI Jakarta, maka dapat ditinjau dengan besarnya potensi pajak langsung yang dapat diperoleh dari platform ini. Menurut Peraturan
Pemerintah Nomor 34 tahun 2017 tentang Pajak Penghasilan Atas Penghasilan dari Persewaan Tanah dan/atau Bangunan, sebagai berikut (Kementerian Hukum dan HAM, 2017):

1. Penghasilan dari persewaan tanah dan/atau Bangunan baik sebagian maupun seluruh Bangunan yang diterima atau diperoleh orang pribadi atau badan (Pasal 2).

2. Besarnya Pajak Penghasilan sebesar $10 \%$ (sepuluh persen) dari jumlah bruto nilai persewaan tanah dan/atau Bangunan (Pasal 4).

Sehingga potensi penerimaan pajak sebesar $10 \%$ dari setiap penerimaan pendapatan terdapat pada Tabel 7.

Berdasarkan Tabel 7, dapat diidentifikasi bahwa potensi besaran pendapatan daerah dari pajak Airbnb dapat mencapai Rp 1,5 Milyar per bulannya. Airbnb dalam ketentuannya sebenarnya menyebutkan bahwa akan selalu siap membantu menghitung, menarik, dan mengirimkan pajak hunian lokal atas nama pemilik di sebagian negara

Tabel 7. Potensi Penerimaan Pajak Daerah dari Platform Airbnb Januari 2017-Juli 2018 (dalam juta Rupiah)

\begin{tabular}{|c|c|c|c|c|c|c|}
\hline Periode & & Entire Home & Private Room & Shared Room & Total Revenue & $\begin{array}{l}10 \% \\
\text { Pajak }\end{array}$ \\
\hline \multirow{12}{*}{2017} & Jan & $4.151,18$ & 504,32 & 18,93 & $4.674,43$ & 467,44 \\
\hline & Feb & $3.179,40$ & 495,27 & 14,53 & $3.689,20$ & 368,92 \\
\hline & Mar & $3.577,28$ & 609,58 & 18,12 & $4.204,98$ & 420,50 \\
\hline & Apr & $4.178,92$ & 603,52 & 17,32 & $4.799,77$ & 479,98 \\
\hline & May & $4.472,69$ & 667,31 & 7,14 & $5.147,14$ & 514,71 \\
\hline & Jun & $4.863,02$ & 695,58 & 10,24 & $5.568,84$ & 556,88 \\
\hline & Jul & $6.127,02$ & 738,55 & 23,38 & $6.888,95$ & 688,89 \\
\hline & Aug & $6.308,18$ & 802,18 & 16,43 & $7.126,79$ & 712,68 \\
\hline & Sep & $5.755,87$ & 735,39 & 9,86 & $6.501,12$ & 650,11 \\
\hline & Oct & $6.657,41$ & 841,16 & 18,07 & $7.516,63$ & 751,66 \\
\hline & Nov & $7.327,52$ & 882,67 & 28,28 & $8.238,46$ & $\mathbf{8 2 3 , 8 5}$ \\
\hline & Dec & $12.047,90$ & $1.289,97$ & 23,17 & $13.361,04$ & $\mathbf{1 . 3 3 6 , 1 0}$ \\
\hline \multirow{7}{*}{2018} & Jan & $8.561,88$ & $1.080,23$ & 5,29 & $9.647,40$ & 964,74 \\
\hline & Feb & $8.498,35$ & 732,53 & 3,28 & $9.234,16$ & 923,42 \\
\hline & Mar & $10.070,60$ & 946,20 & 10,68 & $11.027,48$ & $1.102,75$ \\
\hline & Apr & $8.640,31$ & $1.014,56$ & 8,44 & $9.663,31$ & 966,33 \\
\hline & May & $7.625,80$ & $1.009,99$ & 25,44 & $8.661,23$ & 866,12 \\
\hline & Jun & $10.407,80$ & $1.236,27$ & 10,30 & $11.654,37$ & $1.165,44$ \\
\hline & Jul & $13.116,30$ & $1.321,18$ & 25,25 & $14.462,73$ & $1.446,27$ \\
\hline
\end{tabular}

Sumber: Hasil olahan Penulis, 2020 
di dunia (Airbnb, 2020b). Cara penghitungan pajak hunian bervariasi di setiap yurisdiksi dan pemilik diminta untuk meninjau kembali hukum setempat di wilayahnya sebelum mengiklankan tempat di Airbnb. Ini penting untuk menjadi perhatian pemerintah dalam pengelolaannya, karena sesuai dengan pernyataan (Selloni, 2017), bahwa platform ini umumnya melanggar undangundang dan peraturan perumahan setempat, penghindaran terhadap pajak dan deregulasi terhadap pasar tenaga kerja.

\section{KESIMPULAN DAN REKOMENDASI}

Permintaan wisman dan wisnus terhadap usaha penyediaan akomodasi masih tinggi. Lebih dari $70 \%$ wisman yang keluar melalui pintu Bandara Internasional Soekarno-Hatta memilih untuk menggunakan hotel sebagai tempat menginap. Begitu juga dengan wisnus, di mana sepertiganya memilih untuk menginap di hotel dan sarana akomodasi lainnya sehingga sangat wajar jika usaha penyediaan akomodasi berkembang pesat di Provinsi DKI Jakarta, mengingat jumlah permintaan yang besar terhadap jenis akomodasi tersebut.

Beberapa kesimpulan dapat ditarik untuk menjawab pertanyaan penelitian. Pertama, sejak 2010 sampai dengan 2016, usaha penyediaan akomodasi di DKI Jakarta memiliki ratarata pertambahan jumlah kamar adalah 1.794 per tahun, sedangkan rata-rata pertambahan jumlah tempat tidur adalah 2.484 per tahun. Kedua, sejalan dengan pertumbuhan usaha penyediaan akomodasi di Provinsi DKI Jakarta, perkembangan jumlah listing di provinsi ini juga turut berkembang dengan pesat, bahkan data terakhir bulan Juli 2018 menunjukkan terdapat lebih dari lima ribu listing yang menggunakan Airbnb sebagai sarana untuk penjualannya. Ketiga, saat ini kemunculan platform sharing economy Airbnb, belum memiliki pengaruh signifikan terhadap usaha penyediaan akomodasi di DKI Jakarta. Hasil prediksi menyatakan bahwa apabila kondisi tidak berubah, maka paling cepat platform ini akan berpengaruh terhadap usaha penyediaan akomodasi pada bulan Juni 2023. Hasil ini pun hanya terjadi pada jenis listing entire home yang pada tahun 2023 nanti akan memengaruhi usaha penyediaan akomodasi hotel bintang dan nonbintang. Hal ini disebabkan oleh, pangsa pasar pada wilayah DKI Jakarta merupakan pangsa pasar Bisnis dan Grup, di mana platform Airbnb lebih berfokus pada pangsa pasar individual. Keempat, potensi penerimaan daerah apabila listing yang terdaftar pada Airbnb mengikuti/patuh terhadap peraturan-peraturan yang berlaku dalam hal penyelenggaraan usaha penyediaan akomodasi mencapai lebih dari $\mathrm{Rp}$ 1,5 miliar setiap bulannya.

Penelitian ini juga mengidentifikasi beberapa rekomendasi yang dapat dilakukan terkait potensi dampak Airbnb terhadap usaha penyediaan akomodasi di DKI Jakarta. Pertama, penting untuk juga mengkaji beberapa daerah yang memiliki karakteristik pasar yang berbeda dengan Provinsi DKI Jakarta sehingga penyusunan kebijakan dapat lebih optimal serta tepat guna dan sasaran. Banyaknya negara/kota-kota di dunia yang mengeluarkan peraturan terkait Airbnb, menunjukkan bahwa platform ini juga perlu menjadi perhatian bagi pemerintah. Kasuskasus yang umumnya sama juga dapat terjadi di Indonesia, dan berbagai penanganan dari berbagai negara/kota-kota di dunia dapat menjadi contoh/ benchmarking bagi indonesia dalam merumuskan kebijakan. Beberapa langkah seperti penciptaan "level of playing field", pembatasan waktu aktif, pembatasan kepemilikan listing, pemberlakuan social assessment hingga pemberlakuan zonasi di mana platform ini dapat/tidak diberlakukan, masih membutuhkan beberapa kajian yang lebih menyeluruh agar tepat digunakan. Sehingga, kajian ini dapat menjadi kajian pendahuluan terkait pengaruh kemunculan platform Airbnb ataupun dapat dikembangkan lagi ke platform peer-to-peer economic sharing lainnya di bidang pariwisata. Kedua, pemerintah perlu memastikan peraturan terkait usaha penyediaan akomodasi dipatuhi oleh seluruh pelaku usaha, termasuk mereka yang ingin menggunakan platform Airbnb untuk mengubah peruntukan tempat tinggalnya menjadi usaha penyediaan akomodasi komersial. Selain itu, pemerintah daerah, dalam hal ini pemerintah Provinsi DKI Jakarta perlu merumuskan dan menerapkan peraturan-peraturan tambahan lainnya terkait kepemilikan dan penyewaan jenis usaha berbasis platform Airbnb ataupun 
sejenisnya. Ketiga, penting untuk dapat segera menindaklanjuti kajian ini dengan mengeluarkan kebijakan berbentuk peraturan yang berlandaskan hukum, sehingga Indonesia tidak perlu menunggu munculnya konflik yang lebih besar untuk dapat ditangani. Hal ini juga terkait dengan perkiraan potensi hilangnya pajak dari berkembangnya penyewaan akomodasi berbasis peer-to-peer sharing economy.

\section{DAFTAR PUSTAKA}

Afiyanti, Y. (2008). Focus group discussion (diskusi kelompok terfokus) sebagai metode pengumpulan data penelitian kualitatif. Jurnal Keperawatan Indonesia, 12(1), 58-62. https://doi.org/10.7454/jki. v12i1.201.

Aini, N. (2017). Pemkab Garut tolak operasional ojek online. Retrieved April 26, 2018, from https://www.republika.co.id/berita/ekonomi/ makro/17/08/27/ovc6rj382-pemkab-garuttolak-operasional-ojek-online.

Airbnb. (2020a). Apa penjelasan tentang masingmasing tipe rumah? Retrieved March 14, 2020, from https://www.airbnb.co.id/help/ article/317/apa-penjelasan-tentang-masingmasing-tipe-rumah.

Airbnb. (2020b). Bagaimana pemberlakuan pajak untuk tuan rumah? Retrieved March 14, 2020, from https://www.airbnb.co.id/ help/article/317/apa-penjelasan-tentangmasingmasing-tipe-rumah

Akarsu, T. N., Foroudi, P., \& Melewar, T. C. (2020). What makes Airbnb likeable? Exploring the nexus between service attractiveness, country image, perceived authenticity and experience from a social exchange theory perspective within an emerging economy context. International Journal of Hospitality Management, 91(May), 102635. https://doi. org/10.1016/j.ijhm.2020.102635.

Akbar, Y. H., \& Tracogna, A. (2018). International journal of hospitality management the sharing economy and the future of the hotel industry: Transaction cost theory and platform economics. International Journal of Hospitality Management, 71(April
2017), 91--101. https://doi.org/10.1016/j. ijhm.2017.12.004

Anugrah, A. (2017). Tolak Gojek, Bupati Banyumas rancang JekNyong. Retrieved March 14, 2020, from https://news.detik. com/berita-jawa-tengah/d-3557801/tolakgojek-bupati-banyumas-rancang-jeknyong.

Badan Pusat Statistik. (2018). Perkembangan pariwisata dan transportasi nasional Desember 2017. Jakarta. Retrieved from https://www.bps.go.id/pressrelease/ download.html?nrbvfeve=MTQ2OA\%3D \%3D\&sdfs=ldjfdifsdjkfahi\& twoadfnoarfe auf $=$ MjAyMC0wOC0 $w$ NiAxMToxMTo0 OQ\%3D\%3D

Badan Pusat Statistik. (2020). Sistem informasi rujukan statistik (SIRuSa). Retrieved March 14, 2020, from https://sirusa.bps.go.id/ sirusa/.

Badan Pusat Statistik, \& Kementerian Pariwisata. (2017). Kajian data pasar wisatawan nusantara 2017. (Badan Pusat Statistik, Ed.). Jakarta: Badan Pusat Statistik dan Kementerian Pariwisata. Retrieved from http://beta.kemenpar.go.id/ asset_admin/assets/uploads/media/pdf/ media_1553500574_Publikasi_Kajian Data_Pasar_Wisnus_2017.pdf

Badan Pusat Statistik Provinsi DKI Jakarta. (2011). Jakarta dalam angka 2011. Jakarta. Retrieved from https://jakarta.bps.go.id/pu blication/2012/01/25/2bc157eb132ba603 e8fb36ed/jakarta-dalam-angka-2011.html.

Badan Pusat Statistik Provinsi DKI Jakarta. (2012). Jakarta dalam angka 2012. Jakarta. Retrieved from https://jakarta. bps.go.id/publication/2012/08/16/ ec9b033c35df0d65b37a8997/jakarta-dalamangka-2012.html.

Badan Pusat Statistik Provinsi DKI Jakarta. (2013). Jakarta dalam angka 2013. Jakarta. Retrieved from https://jakarta.bps.go.id/pub lication/2013/08/16/3881d1fcb10d7acb8e88 ec52/jakarta-dalam-angka-2013.html.

Badan Pusat Statistik Provinsi DKI Jakarta. (2014). Jakarta dalam angka 2014. Jakarta. Retrieved from https://jakarta. bps.go.id/publication/2014/10/21/ 
bb081af3fabf3f5432c74056/jakarta-dalamangka-2014.html.

Badan Pusat Statistik Provinsi DKI Jakarta. (2015). Jakarta dalam angka 2015. jakarta. Retrieved from https://jakarta. bps.go.id/publication/2016/02/29/ bafeb8e753144624121e6123/provinsi-dkijakarta-dalam-angka-2015.html//.

Badan Pusat Statistik Provinsi DKI Jakarta. (2016). Jakarta dalam angka 2016. Jakarta. Retrieved from https://jakarta.bps.go.id/pub lication/2016/07/15/0b8db75bbcac8c13b4e 76aaa/jakarta-dalam-angka-2016.html.

Badan Pusat Statistik Provinsi DKI Jakarta. (2017). Jakarta dalam angka 2017. Jakarta. Retrieved from https://jakarta.bps.go.id/ publication/2017/08/16/3e3564fb6453d3 84983128b0/provinsi-dki-jakarta-dalamangka-2017.html.

Cahyani, D. R. (2017). Pengusaha hotel merasa terancam, minta Airbnb dibekukan. Retrieved March 14, 2020, from https://bisnis.tempo. co/read/1036485/pengusaha-hotel-merasaterancam-minta-airbnb-dibekukan.

Demary, V. (2015). Competition in the sharing economy (No. IW Policy Paper 19/2015). Retrieved from https://www.econstor.eu/ bitstream/10419/112778/1/830325093.pdf.

Dewi, N. P., \& Listiowarni, I. (2020). View of implementasi holt-winters exponential smoothing untuk peramalan harga bahan pangan di Kabupaten Pamekasan. Digital Zone: Jurnal Teknologi Informasi Dan Komunikasi, 11(2), 219--231. https://doi. org/https://doi.org/10.31849/digitalzone. v11i2.4797

Dredge, D., \& Gyimothy, S. (2017). Collaborative economy and tourism: perspectives, politics, policies and prospects. (P. J. Sheldon \& D. R. Fesenmaier, Eds.) (Tourism on). Copenhagen: Springer. https://doi. org/10.1007/978-3-319-51799-5 ISSN

Erlangga, P. (2017). Ditolak di Bukittinggi, Go-Jek: Tidak masalah. Retrieved March 14, 2020, from https://bisnis.tempo.co/ read/899190/ditolak-di-bukittinggi-go-jektidak-masalah
Fitriyani, E. (2017). 5 fakta yang muncul dari perseteruan PHRI dengan Airbnb. Retrieved March 14, 2020, from https://kumparan. com/kumparanbisnis/5-fakta-yang-munculdari-perseteruan-phri-dengan-airbnb

Garcia-López, M. À., Jofre-Monseny, J., Martínez-Mazza, R., \& Segú, M. (2020). Do short-term rental platforms affect housing markets? Evidence from Airbnb in Barcelona. Journal of Urban Economics, 119(August). https://doi.org/10.1016/j. jue.2020.103278

Geerts, W. (2016). New global briefing: The sharing economy in lodging. Retrieved March 14, 2020, from https://blog. euromonitor.com/new-global-briefing-thesharing-economy-in-lodging/

Guttentag, D., \& Smith, L. (2017). Assessing Airbnb as a disruptive innovation relative to hotels substitution and comparative performance expectations. International Journal of Hospitality Management, 64, 1-10. https://doi.org/10.1016/j. ijhm.2017.02.003

Haviluddin, H., Cahyadi, D., \& Mulawarman, U. (2016). Prediksi kedatangan turis asing ke Indonesia menggunakan backpropagation neural networks. Jurnal Teknologi Dan Sistem Komputer, 4(4), 485-490. https://doi. org/10.14710/jtsiskom.4.4.2016.485-490

Hidayah, S. A., \& Utami, R. C. (2015). Passanger exit survey 2015. Jakarta. Retrieved from https://www.kemenparekraf.go.id/asset_ admin/assets/uploads/media/old_file/Buku PES 2015.pdf

Juul, M. (2015). The sharing economy and tourism tourist accommodation. Retrieved from https://www.europarl.europa.eu/ RegData/etudes/BRIE/2015/568345/ EPRS_BRI(2015)568345_EN.pdf

Kementerian Hukum dan HAM. (2009). UndangUndang Republik Indonesia Nomor 10 Tahun 2009 Tentang Kepariwisataan, Pub. L. No. 10/2009 Tentang Kepariwisataan, 1 (2009). Indonesia.

Kementerian Hukum dan HAM. (2017). Peraturan Pemerintah Nomor 34 tahun 2017 tentang Pajak Penghasilan Atas Penghasilan dari 
Persewaan Tanah dan/atau Bangunan, Pub. L. No. Peraturan Pemerintah Nomor 34 tahun 2017 tentang Pajak Penghasilan Atas Penghasilan dari Persewaan Tanah dan/atau Bangunan (2017). Indonesia.

Liem, C. (2016). The rise of the sharing economy in Indonesia. Retrieved March 14, 2020, from https://www.weforum.org/ agenda/2016/01/the-rise-of-the-sharingeconomy-in-indonesia/

Makridakis, S. G., Wheelwright, S. C., \& Hyndman, R. J. (1997). Forecasting: Methods and applications. New York: Wiley.

Mulyadi, M. (2011). Penelitian kuantitatif dan kualitatif serta pemikiran dasar menggabungkannya. Jurnal Studi Komunikasi dan Media, 15(1), 127-138. https://doi.org/DOI 10.1016/j. chemphys.2012.06.006

Nurlaila, E. (2017). Airbnb mulai ganggu bisnis perhotelan di Indonesia. Retrieved March 14, 2020, from https://kumparan.com/@ kumparanbisnis/airbnb-mulai-ganggubisnis-perhotelan-di-indonesia

Paramita, A., \& Kristiana, L. (2013). Teknik focus group discussion dalam penelitian kualitatif. Buletin Penelitian Sistem Kesehatan, 16(2), 117-127. Retrieved from https://media. neliti.com/media/publications/20840-IDteknik-focus-group-discussion-dalampenelitian-kualitatif.pdf

Prakoso, J. R. (2017). Ada penolakan akomodasi non hotel, Airbnb siap kerja sama. Retrieved March 14, 2020, from https://travel.detik. com/travel-news/d-3731688/ada-penolakanakomodasi-non-hotel-airbnb-siap-kerjasama

Rachmat, R., \& Suhartono, S. (2020). Comparative analysis of single exponential smoothing and holt's method for quality of hospital services forecasting in general hospital. Bulletin of Computer Science and Electrical Engineering. https://doi.org/10.25008/ bcsee.v1i2.8

Raihan, Effendi, M. S., \& Hendrawan, A. (2016). Forecasting model eksponensial smoothing time series rata rata mechanical availability unit off highway truck cat $777 \mathrm{~d}$ caterpillar. Poros Teknik, 8(1), 1-9. https:// doi.org/10.31961/porosteknik.v8i1.375

Sahroji, A. (2017). Tak hanya Jabar, lima daerah ini juga larang transportasi online beroperasi. Retrieved March 14, 2020, from https://nasional.okezone. com/read/2017/10/11/337/1793462/takhanya-jabar-lima-daerah-ini-juga-larangtransportasi-online-beroperasi

Saputra, A. D. (2017). Polisi datangi kantor Gojek Kediri, antisipasi penolakan opang. Retrieved March 14, 2020, from https://news. detik.com/berita-jawa-timur/d-3621950/ polisi-datangi-kantor-gojek-kediriantisipasi-penolakan-opang

Saputra, P., \& Hayatin, N. (2019). Model platform sharing economy di Indonesia study kasus: Unicorn lokal. Jurnal Dialektika, 4(2), 55-65. Retrieved from http://www.ejournal. uniramalang.ac.id/index.php/dialektika/ article/view/350

Sbrana, G., \& Silvestrini, A. (2014). Random switching exponential smoothing and inventory forecasting. International Journal of Production Economics, 156, 283-294. https://doi.org/10.1016/j.ijpe.2014.06.016

Selloni, D. (2017). Co design for public-interest services. (E. Bartezzaghi \& G. Bracchi, Eds.) (Research f). Milan: Springer. https://doi. org/10.1007/978-3-319-53243-1

Setiawan, D. (2017). Ratusan awak angkot Salatiga mogok tolak kehadiran Gojek. Retrieved March 14, 2020, from https:// jateng.tribunnews.com/2017/08/21/ ratusan-awak-angkot-salatiga-mogok-tolakkehadiran-gojek

Soni, A. (2016). Penolakan kawasan wisata pada Gojek, Grab dan taksi Uber. Retrieved March 14, 2020, from https:// www.kompasiana.com/takutpada-allah1569e055daf7a61a312eea04d/penolakankawasan-wisata-pada-gojek-grab-dan-taksiuber 
Potensi dampak Airbnb terhadap usaha penyediaan akomodasi di Provinsi DKI Jakarta

\section{Appendix 1}

Perbandingan Tingkat Hunian Kamar Entire Home, Private Room, dan Shared Room dengan Hotel Bintang dan Non Bintang di Provinsi DKI Jakarta.

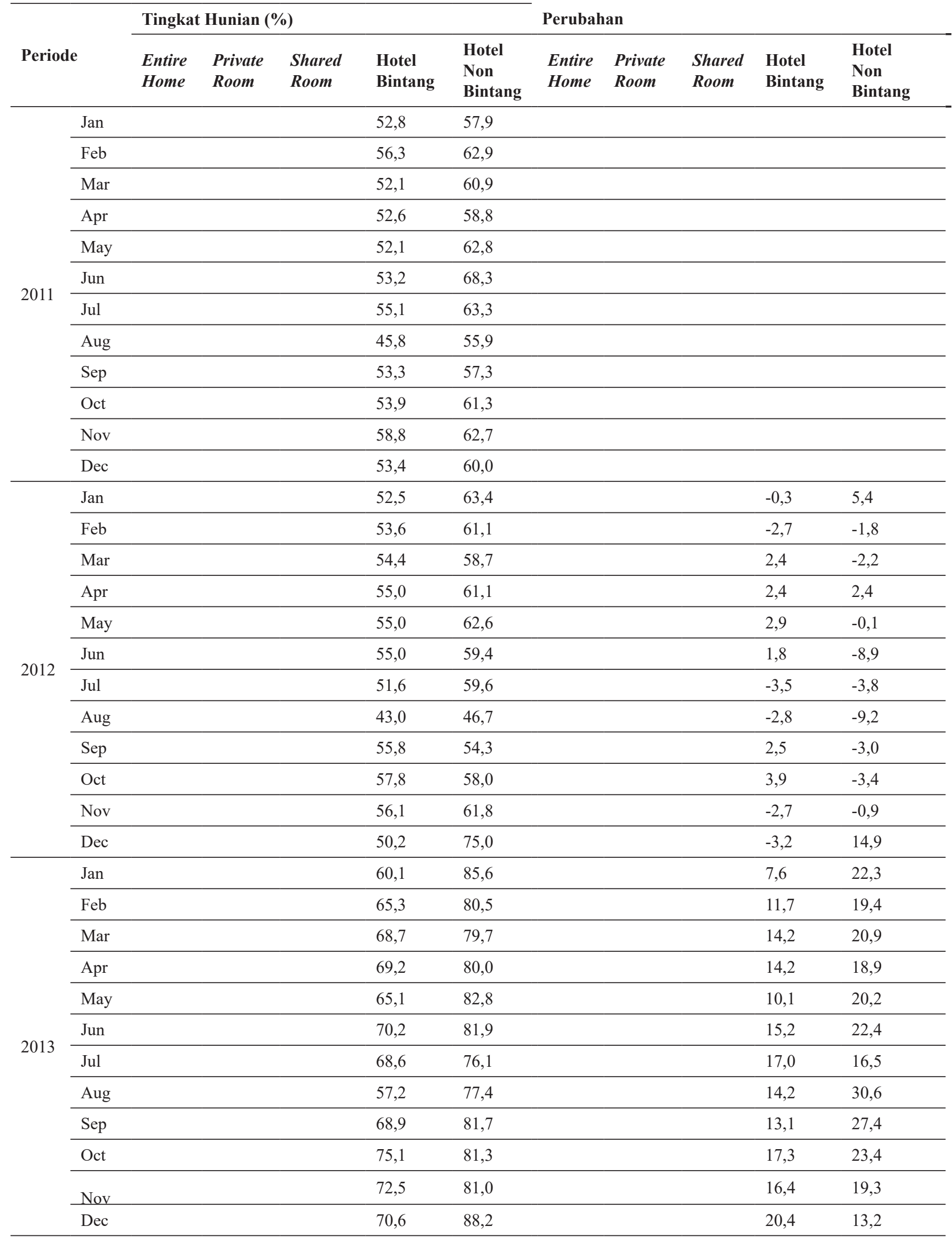


Addin Maulana, M. Iqbal Rosyidi, Chamma Fitri Putri Pradjwalita Koesfardani, Septia Awal Hidayah, I Dewa Gede Richard Alan Amory

\begin{tabular}{|c|c|c|c|c|c|c|c|c|c|c|c|}
\hline & & Tingka & Hunian ( & & & & Perubal & & & & \\
\hline Period & & Entire & Private & Shared & Hotel & Hotel & Entire & Private & Shared & Hotel & Hotel \\
\hline & Jan & & & & 48,7 & 60,2 & & & & $-11,3$ & $-25,5$ \\
\hline & Feb & & & & 53,3 & 64,5 & & & & $-12,0$ & $-16,0$ \\
\hline & Mar & & & & 51,4 & 61,0 & & & & $-17,2$ & $-18,6$ \\
\hline & Apr & & & & 51,8 & 64,7 & & & & $-17,4$ & $-15,3$ \\
\hline & May & & & & 52,5 & 62,3 & & & & $-12,6$ & $-20,5$ \\
\hline & Jun & & & & 58,0 & 62,6 & & & & $-12,1$ & $-19,3$ \\
\hline 2017 & Jul & & & & 43,7 & 53,2 & & & & $-24,9$ & $-22,9$ \\
\hline & Aug & & & & 52,4 & 60,4 & & & & $-4,9$ & $-16,9$ \\
\hline & Sep & & & & 56,3 & 62,4 & & & & $-12,6$ & $-19,3$ \\
\hline & Oct & & & & 56,7 & 61,7 & & & & $-18,4$ & $-19,6$ \\
\hline & Nov & & & & 54,9 & 71,9 & & & & $-17,6$ & $-9,2$ \\
\hline & Dec & & & & 52,0 & 67,8 & & & & $-18,6$ & $-20,4$ \\
\hline & Jan & & & & 61,5 & 80,4 & & & & 12,8 & 20,2 \\
\hline & Feb & & & & 51,1 & 86,1 & & & & $-2,2$ & 21,5 \\
\hline & Mar & & & & 65,1 & 86,0 & & & & 13,7 & 24,9 \\
\hline & Apr & & & & 62,8 & 78,5 & & & & 11,0 & 13,8 \\
\hline & May & & & & 61,8 & 78,9 & & & & 9,2 & 16,6 \\
\hline 2015 & Jun & & & & 60,0 & 82,2 & & & & 2,0 & 19,6 \\
\hline 2010 & Jul & & & & 52,3 & 76,1 & & & & 8,6 & 23,0 \\
\hline & Aug & 29,4 & 19,0 & 29,4 & 63,3 & 80,2 & & & & 11,0 & 19,7 \\
\hline & Sep & 27,3 & 16,9 & 31,3 & 56,7 & 84,3 & & & & 0,4 & 21,8 \\
\hline & Oct & 27,2 & 15,1 & 11,8 & 60,3 & 83,3 & & & & 3,6 & 21,6 \\
\hline & Nov & 25,0 & 15,5 & 5,3 & 58,5 & 79,7 & & & & 3,6 & 7,9 \\
\hline & Dec & 36,3 & 21,4 & 14,3 & 64,5 & 82,4 & & & & 12,5 & 14,6 \\
\hline & Jan & 31,3 & 18,5 & 28,6 & 54,2 & 60,8 & & & & $-7,3$ & $-19,6$ \\
\hline & Feb & 24,4 & 15,3 & 26,3 & 58,6 & 61,2 & & & & 7,6 & $-24,9$ \\
\hline & Mar & 29,2 & 19,0 & 17,4 & 61,8 & 71,5 & & & & $-3,3$ & $-14,5$ \\
\hline & Apr & 34,6 & 21,2 & 20,8 & 60,5 & 60,5 & & & & $-2,3$ & $-18,1$ \\
\hline & May & 41,7 & 24,3 & 18,5 & 59,5 & 64,7 & & & & $-2,3$ & $-14,3$ \\
\hline 2016 & Jun & 34,8 & 23,5 & 22,7 & 60,0 & 77,6 & & & & 0,0 & $-4,6$ \\
\hline & Jul & 33,7 & 21,3 & 23,3 & 55,6 & 69,9 & & & & 3,3 & $-6,2$ \\
\hline & Aug & 31,1 & 19,1 & 19,4 & 69,8 & 66,9 & 1,7 & 0,2 & $-10,1$ & 6,5 & $-13,2$ \\
\hline & Sep & 32,2 & 20,3 & 25,0 & 63,0 & 66,0 & 4,9 & 3,4 & $-6,3$ & 6,3 & $-18,3$ \\
\hline & Oct & 33,7 & 17,2 & 19,0 & 75,1 & 79,9 & 6,6 & 2,1 & 7,3 & 14,8 & $-3,4$ \\
\hline & Nov & 31,2 & 16,7 & 9,1 & 68,1 & 65,3 & 6,2 & 1,1 & 3,8 & 9,5 & $-14,4$ \\
\hline & Dec & 42,5 & 21,7 & 20,4 & 62,8 & 86,6 & 6,2 & 0,3 & 6,1 & $-1,7$ & 4,2 \\
\hline
\end{tabular}


Potensi dampak Airbnb terhadap usaha penyediaan akomodasi di Provinsi DKI Jakarta

\begin{tabular}{|c|c|c|c|c|c|c|c|c|c|c|c|}
\hline \multirow[b]{2}{*}{ Period } & & \multicolumn{5}{|c|}{ Tingkat Hunian (\%) } & \multicolumn{5}{|c|}{ Perubahan } \\
\hline & & $\begin{array}{l}\text { Entire } \\
\text { Home }\end{array}$ & $\begin{array}{l}\text { Private } \\
\text { Room }\end{array}$ & $\begin{array}{l}\text { Shared } \\
\text { Room }\end{array}$ & $\begin{array}{l}\text { Hotel } \\
\text { Bintang }\end{array}$ & $\begin{array}{l}\text { Hotel } \\
\text { Non } \\
\text { Bintang }\end{array}$ & $\begin{array}{l}\text { Entire } \\
\text { Home }\end{array}$ & $\begin{array}{l}\text { Private } \\
\text { Room }\end{array}$ & $\begin{array}{l}\text { Shared } \\
\text { Room }\end{array}$ & $\begin{array}{l}\text { Hotel } \\
\text { Bintang }\end{array}$ & $\begin{array}{l}\text { Hotel } \\
\text { Non } \\
\text { Bintang }\end{array}$ \\
\hline \multirow{12}{*}{2017} & Jan & 38,9 & 20,9 & 36,0 & 56,8 & & 7,6 & 2,4 & 7,4 & 2,5 & \\
\hline & Feb & 32,4 & 19,2 & 28,0 & 61,8 & & 8,0 & 3,9 & 1,7 & 3,2 & \\
\hline & Mar & 31,6 & 20,1 & 20,0 & 64,3 & & 2,4 & 1,2 & 2,6 & 2,5 & \\
\hline & Apr & 38,5 & 22,9 & 22,7 & 59,2 & & 3,9 & 1,7 & 1,9 & $-1,4$ & \\
\hline & May & 33,6 & 21,8 & 13,7 & 65,3 & & $-8,1$ & $-2,5$ & $-4,8$ & 5,8 & \\
\hline & Jun & 37,5 & 19,4 & 16,0 & 54,5 & & 2,7 & $-4,1$ & $-6,7$ & $-5,6$ & \\
\hline & Jul & 38,7 & 22,0 & 21,3 & 62,2 & & 5,0 & 0,7 & $-2,1$ & 6,6 & \\
\hline & Aug & 38,6 & 23,1 & 17,3 & 68,2 & & 7,5 & 4,0 & $-2,1$ & $-1,7$ & \\
\hline & Sep & 36,4 & 21,7 & 17,3 & 68,1 & & 4,2 & 1,4 & $-7,7$ & 5,1 & \\
\hline & Oct & 40,5 & 20,6 & 21,0 & 65,2 & & 6,8 & 3,4 & 1,9 & $-9,8$ & \\
\hline & Nov & 43,7 & 23,9 & 22,9 & 67,3 & & 12,5 & 7,3 & 13,8 & $-0,8$ & \\
\hline & Dec & 52,6 & 27,0 & 28,9 & 66,4 & & 10,1 & 5,3 & 8,5 & 3,6 & \\
\hline \multirow{7}{*}{2018} & Jan & 43,0 & 21,9 & 7,3 & 64,7 & & 4,1 & 1,0 & $-28,7$ & 8,0 & \\
\hline & Feb & 40,1 & 18,2 & 7,2 & 62,4 & & 7,7 & $-1,0$ & $-20,8$ & 0,6 & \\
\hline & Mar & 42,2 & 20,4 & 12,6 & 61,8 & & 10,5 & 0,3 & $-7,4$ & $-2,5$ & \\
\hline & Apr & 41,6 & 21,6 & 11,5 & 62,9 & & 3,1 & $-1,3$ & $-11,2$ & 3,7 & \\
\hline & May & 44,8 & 24,3 & 28,6 & 65,6 & & 11,2 & 2,5 & 14,9 & 0,3 & \\
\hline & Jun & 43,4 & 21,2 & 11,1 & 52,5 & & 5,9 & 1,8 & $-4,9$ & $-2,0$ & \\
\hline & Jul & 46,9 & 23,0 & 14,8 & 78,8 & & 8,2 & 1,0 & $-6,5$ & 16,6 & \\
\hline
\end{tabular}

Sumber: Hasil olahan Penulis (2020) 


\section{Appendix 2}

Tingkat Penghunian Kamar (TPK) Hotel Bintang dengan Airbnb Entire Home

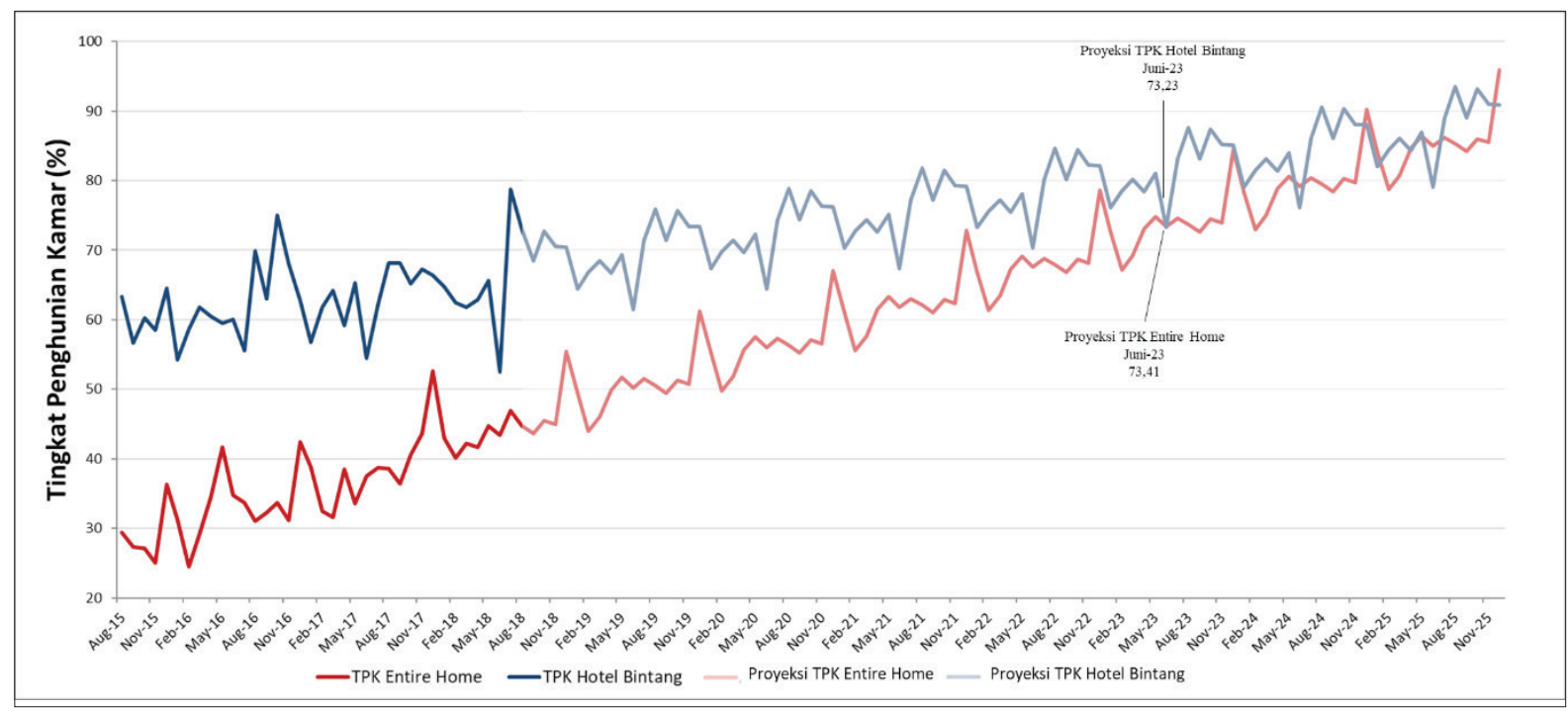

Sumber: Hasil olahan Penulis (2020)

\section{Appendix 3}

Tingkat Penghunian Kamar (TPK) Hotel Non Bintang dengan Airbnb Entire Home

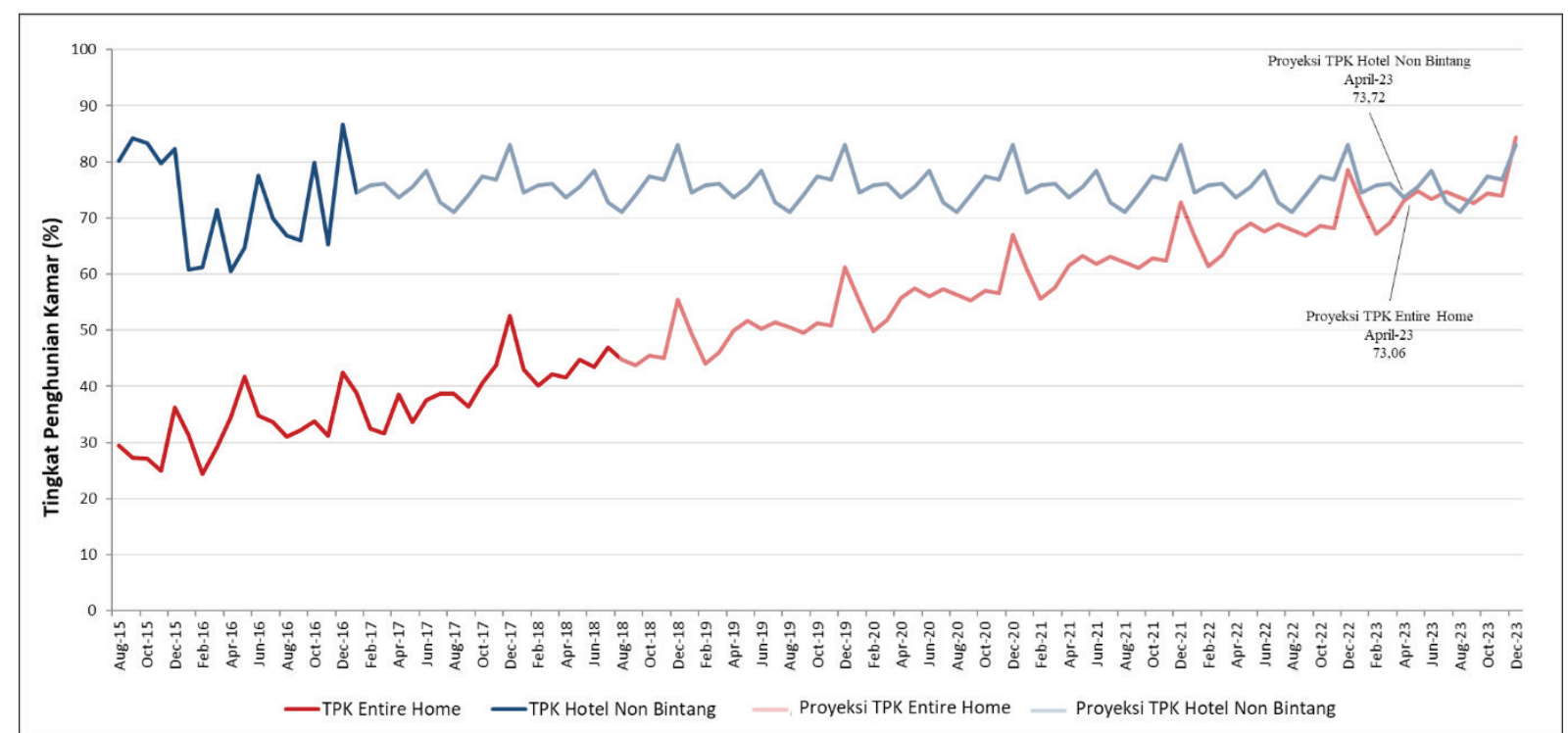

Sumber: Hasil olahan Penulis (2020) 


\section{Appendix 4}

Tingkat Penghunian Kamar (TPK) Hotel Non Bintang dengan Airbnb Entire Home

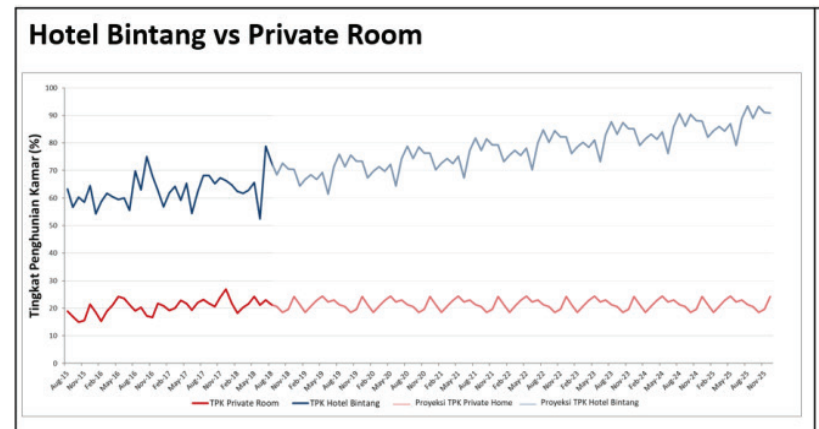

Hotel Bintang vs Shared Room

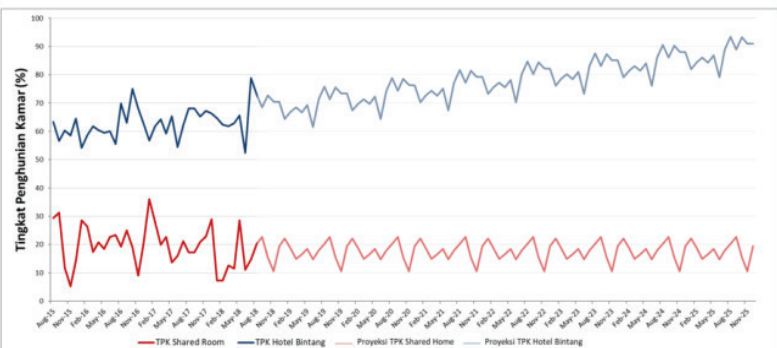

\section{Hotel Non Bintang vs Private Room}

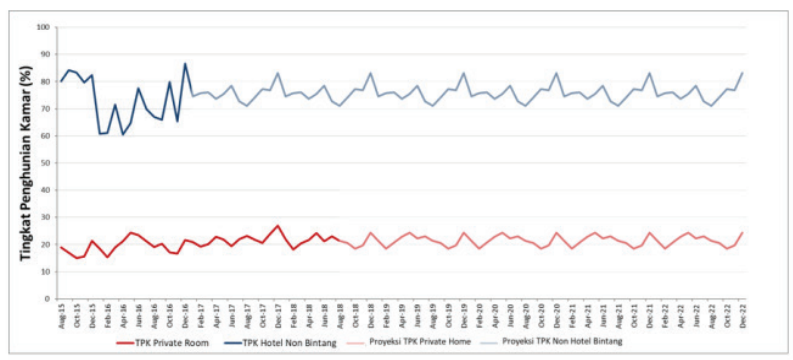

Hotel Non Bintang vs Shared Room

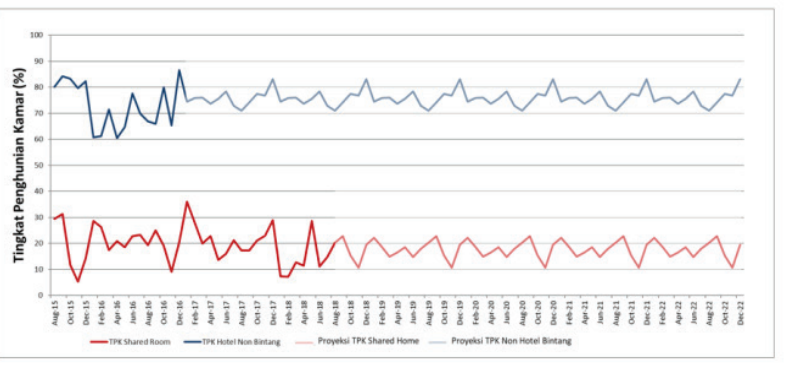

Sumber: Hasil olahan Penulis (2020) 